\title{
Industrial Location in Greece: Fostering Green Transition and Synergies between Industrial and Spatial Planning Policies
}

\author{
Anestis Gourgiotis $^{1}$ (D), Stella Sofia Kyvelou ${ }^{2, *}$ id and Ioannis Lainas ${ }^{1}$ (D \\ 1 Department of Planning and Regional Development, University of Thessaly, 38334 Volos, Greece; \\ gourgiotis@uth.gr (A.G.); iolainas@uth.gr (I.L.) \\ 2 Department of Economic and Regional Development, Panteion University of Social and Political Sciences, \\ 17671 Athens, Greece \\ * Correspondence: kyvelou@panteion.gr
}

check for updates

Citation: Gourgiotis, A.; Kyvelou, S.S.; Lainas, I. Industrial Location in Greece: Fostering Green Transition and Synergies between Industrial and Spatial Planning Policies. Land 2021, 10, 271. https://doi.org/10.3390/ land10030271

Academic Editor: Jefferey M. Sellers

Received: 28 January 2021

Accepted: 4 March 2021

Published: 6 March 2021

Publisher's Note: MDPI stays neutral with regard to jurisdictional claims in published maps and institutional affiliations.

Copyright: (c) 2021 by the authors. Licensee MDPI, Basel, Switzerland. This article is an open access article distributed under the terms and conditions of the Creative Commons Attribution (CC BY) license (https:/ / creativecommons.org/licenses/by/ $4.0 /)$.

\begin{abstract}
Greece represents a very peculiar case of industrial development due to a series of historical evolutions. Hence, the present paper aims to discuss the shift from the unregulated and unplanned spatial development paradigm of productive activities to the one of modern "Business parks" (hereinafter BPs), expected to adapt to international standards the location and function of industrial activity, in the Greek territory. Inherent problems and constraints hampering the modernization of industrial development are presented and specific policy recommendations are formulated, with the aim of embedding the industrial parks in sustainable territorial development. This is done through a four-step methodology including (a) an inventory of BPs from the international milieu and the review of current trends in view of the green transition, (b) an analysis of the effects of Greek regulations on the development of the so-called "Organized Receptors of Manufacturing and Business Activities" (OYMEDs) and the suggestion of guiding principles as BPs become more attractive, and (c) the construction of a system of indicators that may govern the transformation of existing parks into eco-industrial parks (EIPs) and monitor their multiple performances. Lastly, an attempt to apply this system of indicators on a national and local level was carried out. Findings show that the regulatory and operational framework concerning BPs in Greece requires a comprehensive revision so as to (a) increase synergies of BPs with the implemented or planned territorial policies, (b) establish collaborative mechanisms acting as catalysts of creativity and innovation, (c) introduce a system of indicators to monitor the development of BPs on the basis of the international framework for eco-industrial parks (EIPs), and (d) pursue an evidence-based industrial policy on national and local levels. A critical outcome is also that strong coordination between spatial and industrial policy is needed, through a high-level inter-ministerial body.
\end{abstract}

Keywords: industrial location; green transition; sustainable territorial development; business parks; organized hosts of manufacturing and business activities; urban ecosystem; eco-industrial parks

\section{Introduction}

The decision to locate a business unit is an extremely important and complex one, as many different factors are weighed before the final decision. The location of a business park (and of an economic activity in general) is a very critical issue both for the economic function itself and for its coexistence and interactions with the area in which it is embedded [1]. There are complex links and dependencies between spatial planning and the local or regional economy, which can cause changes in the urban development model or even spatial reorganization. This is why coordination between spatial planning and economic development policies is required. In particular, according to [2], urban planning, through its various missions, seeks to shape and control the market that drives changes in a capitalist economy. One of these operations is to organize land use, interconnections, and communication systems so as to contribute to greater market efficiency and to the development of the urban economy. 
It is, therefore, no coincidence that the issue of industrial location has been-and, to some extent, still remains to this day-one of the major research topics [3]. Fostering industry at national or European level through the spatial planning process ensures a high standard of living and maintains or improves existing social conditions [4]. The industrial activity offers employment and generates income in its area of establishment. It transforms the structure of local labor markets and brings about changes in lifestyle, forms of social interaction, and prevailing cultural standards. It attracts a population by creating jobs and increases the need for infrastructure and urban services. Urbanization, in turn, favors the attraction of industrial or other economic activities, which reinforce the trends for even greater urban development in the wider area/territory. Thus, industrialization and urbanization are two interdependent processes, each being the cause and simultaneously the effect of the other, as the two sides of the same coin: territorial economic development [5].

In this context, the research identifies several policy gaps regarding the evolution of business parks (BPs), in Greece, since the country represents a peculiar case of industrial development. Due to a series of historical circumstances, Greece was not involved in the first wave of industrial development that took place in the 19th and early 20th century. Greek industry developed in a peculiar "island" environment [6], without neighboring markets and essentially without a hinterland of a corresponding level of development, since the country's northern borders formed the boundary between Europe's two political and military blocs. Thus, it found itself geographically isolated in relation to the developed markets of Western Europe and also unable to ripen, because of this high degree of peripherality of important economic relations with its neighboring countries. These countries followed a centrally planned economic and political model, and they were also considered for a long time as hostile states.

Thus, the paper deals with the organization and spatial distribution of industrial activities in Greece and the current endeavor to renew the industrial location in the country. In the mid-1960s, the country introduced "industrial areas" (law 4458/1965), succeeded some 30 years later by the "industrial and business areas" ( law 2545/1997) and, later on, by today's business parks (law 3882/2011), initiated in 2011 at the height of the economic crisis. Despite these efforts, the organization of industrial activities still remains occasionally inconsistent with the guidelines and rules laid down by the spatial and urban planning framework. Moreover, the most recent law (2011) governing the development of "business parks", being a modern form of organized location of business activities, has not yielded the desired growth. Only five business areas have been included and are currently developing under its provisions. The various development and spatial planning tools have consistently failed over the years to adapt and/or keep pace with the specific needs and requirements of the industry sector (in contrast, for instance, with tourism), resulting in a lack of coordination between spatial and industrial policies. This generated several social, economic, and environmental impacts.

The research acknowledges that, in recent decades, global economy is profoundly influenced by technological change, forcing the production process to be flexible and adaptable. Thus, the overall objective of the article is to investigate the importance of business parks (BPs) for industrial development by (a) providing considerations, from different theoretical schools and (b) critically analyzing the role of business parks (BPs) in Greece. Specific objectives include the identification of the key factors shaping the location of enterprises within BPs and of those generating attractiveness and competitiveness of BPs, to empower them against current and future challenges. To this end, the following key research steps are undertaken: (a) elaborating a series of indicators to assess and monitor the development and performance of BPs and their conversion to eco-industrial parks; (b) assessing the application of these indicators on both a country and a local level, with the latter concerning a specific BP located in Western Macedonia currently under de-lignification; (c) suggesting key guiding principles to increase the attractiveness of Greek business parks following current relevant trends. 


\section{Theoretical Considerations}

A major stream of work under the "behavioral school" has focused on the study of the "geography of enterprises" [7-10]. According to this, the location of industrial activities is not solely determined by individual actions but is also dependent on the strategy of large business units, playing an important role in shaping territories. The issue of location is, therefore, extremely complex and concerns the organization of space within the internal network of functions of large enterprises, rather than the optimal location of their individual production units. Those enterprises are complex organizations consisting of different departments and functions that require different approaches in terms of location. According to the "structural school" - or school of political economy-the location of enterprises is not simply a technical problem of minimizing cost and maximizing revenue (neo-classical school) or a problem of satisfactory decisions on the location of complex organizations (behavioral school), but a complex, conflictual social process [11].

It is, therefore, evident that the issue is approached by different schools of thought in different ways. However, the rapid economic and social evolutions, as well as of technology, keep imposing new location factors, leading to continuous research and the adaptation of industry to the new realm. In particular, a series of new issues currently influence industrial location such as modern technology, production automations, other structural changes in industrial production, evolutions in transport and communication, new energy sources, market globalization, emergence of multinational enterprises, and the creation of "organized receptors" for industry.

The French economists Perroux [12] and Boudeville [13] argue that spatial and industrial development do not appear everywhere and all at once but in specific places, creating "growth poles" of varying intensities. Growth is diffused through various networks, causing differentiated end results across the economy [14]. According to the "growth poles" theory [12], the concentration of economic activities in a rundown city-center urban area will contribute to an increase in regional income as a whole, and this increase will be greater if economic activities are concentrated and not distributed-whether uniformly or in an unregulated way-in the wider area. Achieving this and the "growth poles" policy requires major public investments in social infrastructure, so as to create significant agglomeration economies. It is, therefore, necessary, first and foremost, to select all the locations where infrastructure works are to be carried out. On the other hand, in order for private investments to contribute to this "self-sustaining process", a choice must be made of a number of sectors identified as "promotional industries". These belong to fast-growing and high-tech sectors, contributing to channeling technological and institutional innovation to the region and creating faster income growth in primary and tertiary enterprises. Jointly with the promotional industries, the "polarization process mechanism" [14] is also operating, meaning that growth created by industrial polarization results in the concentration of economic activities in a very small number of centers within the region, whilst the dynamic development of the promotional industries radially diffuses to cover the whole region, being the pole's zone of influence. To make better use of the results from applying the "growth poles" theory, Richardson [15] argues that growth points should not be randomly identified, but instead should be planned with a view to maximizing growth in the surrounding zone of influence without sacrificing the effectiveness of their choice.

This theory supports also the observation that cities are the nuclei of an area's territorial capital [16-18], which consists of the city's geographic location, size, human resources, economic activities and factors of production, climate, natural resources, traditions, quality of life, and economies of scale [19]. Location has always defined the basis of a city's "comparative advantage", while economic strategies at local level were-and still are-aimed at creating new local capital. Part of these economic strategies is the choice regarding the location of economic and other activities that are a crucial element of the cities' own policy to promote themselves in inter-regional and international competition. This "place making" strategy also focuses, among other things, on "urban quality" as a core capital of the city [1]. It is also part of territorial/city marketing, being a tool for spatial/territorial 
development and planning [16], i.e., the political promotion of the city in order to increase its attractiveness. Thus, spatial planning seeks to optimize land-use choices as an element of attracting investment and visibility for cities. This trend is particularly evident in the international competition between cities, much more so between global metropolises.

Global competitiveness is increasingly dependent on innovation and flexible alliances between specialized enterprises. On the other hand, a significant part of business and innovative activity comes from small and medium-sized enterprises [20], which in order to grow need suppliers, facilities, and labor markets of an appropriate scale. This makes local concentrations, the so-called "clusters" [21], particularly important. Thus, while small and medium-sized enterprises are the cornerstone of European economy, representing $99 \%$ of all enterprises, $67 \%$ of all jobs, and nearly $60 \%$ of added value in the EU [22], clusters have also been renowned as an important element of regional industrial landscapes and key drivers for increasing business competitiveness. Insofar as business parks are one of the key instruments for the creation and support of clusters, initiatives are needed to jointly promote them in existing and future spatial and development policies.

The analysis of industrial clusters was introduced more than one century ago by Alfred Marshall, the "father" of industrial regions [23], who argued that, firstly, a cluster can effectively support specialized suppliers, secondly, that the geographic accumulation of industries enables concentration in the labor market, and, thirdly, that the geographic concentration of industrial activities supports the strengthening of knowledge spillovers. Porter [24] also stressed the role of clusters as systems of interrelated enterprises and organizations whose total value exceeds the sum of its parts. He defined clusters as a group of interconnected enterprises and organizations with geographic proximity, operating in a particular sector and linked through joint actions and complementarities. On the other hand, according to the concept of "diversity of externalities" endorsed by Jacobs in 1969 [25], the diffusion of knowledge between businesses does not work so much within the same industry, but rather between different sectors. For this reason, the cities that are portrayed by a wide variety of activities are the main source of innovation [18]. In other words, clustering is seen as an important cradle of "competitive advantage" and innovation in the global economy [24], as well as in cities and regional urban networks.

Business clusters have been and still are a key vehicle for concrete initiatives and policies aimed at coordinating actions for economic growth and prosperity [26]. According to Porter who, as already mentioned, restated and enriched the premises put forward by Marshall in 1920 [23], the significance of the clusters' contribution to economic growth is due to the fact that the geographic concentration of activity in a particular economic sector enterprise produces several externalities. The enterprises within the cluster can benefit from these externalities, such as access to skilled labor and services, particular inputs and infrastructures, and knowledge and information diffusion. In addition, other works highlight the benefits of clusters for the development of a "competitive advantage". This includes better and cheaper access to support industries, production inputs, various institutional bodies, and government services [27]. Clusters are also viewed as dynamic correlations, based on knowledge creation, increased revenue, and innovation through the transfer of information, know-how, and expertise [28]. Furthermore, it was observed that successful clusters tend to create more start-ups internally, compared to cluster-free areas [29,30]. Lastly, according to Klepper [31], businesses are further distinguished, in terms of the skills developed during their life cycle [31], often exhibiting different growth rates due to differentiated experiences and skills before joining the cluster. Relevant examples are the "spin-offs", which have more potential when created by successful companies, in the same or another related sector, and which tend to outperform the other types of companies joining the cluster.

Relevant is also the Coase theorem for planning which affirms that, in dealing with externalities, where transaction costs are insignificant and property rights can be clearly ascribed, market transactions can lead to more efficient outcomes than state interventions, regardless of the initial allocation of resources. The theorem claims that regulating externali- 
ties is not always necessary, provided that property rights are clarified and transaction costs minimized. Since neither zero transaction costs nor fully defined and tradable property rights exist in the real world, the theorem is concerned with accounting for the costs of coordination and the definition of property rights, as well as the role of government in reducing these costs and clarifying property rights [32]. Transaction costs are incurred to increase available information and decrease uncertainty. Appreciating the transaction costs in a development process, one can compare ways of coordinating the development processes [33].

This theory develops in the light of the consideration of transaction costs into planning theory. Planning is treated from a transaction-cost perspective as being a process of coordination used in institutional economics [34]. Healey [35] defines land development processes as the transformation of the physical form, bundle of rights, and material and symbolic value of land and buildings from one state to another. This occurs through the effort of agents with interests and purposes in obtaining and using resources, operating rules, and applying and developing ideas and values.

By this logic, we may use the land improvement syndicates (LIS) Swiss policy tool, designed to assist local authorities and landowners where property rights are not sufficiently defined, where redistribution of development is needed, and where this affects many landowners. LIS facilitates landowner agreement by bringing landowners together, setting forth ground rules on collective decision-making processes, providing reliable and equitable access to information for involved actors, economizing on planning and development costs, and clarifying and reallocating property rights. The results embrace significant implications for planning theory and practice. LIS provide an alternative means to more direct forms of government intervention, internalizing externalities and coping with market failures [32].

\section{Materials and Methods}

\subsection{Materials and Methodology Used for the Analysis}

This paper concerns a critical analysis of the role of business parks (hereinafter BPs) in Greece. It emphasizes the importance of the concept of location for their development and the need to adapt to the international eco-industrial parks (EIPs) framework, thus following current trends of industrial development. Hence, a number of research questions are explored such as the following:

- What is the current situation of business parks in Greece and what are the reasons for BPs being unable to convince companies of the substantial benefits they provide?

- What are the reasons that impeded the timely creation of business parks in Greece, while internationally they are a well-established practice for attracting investment and fostering investment security, as well as supporting industrial production and environmental protection?

- What are the conditions for the development of modern business parks in the country?

- What are the critical factors that need to be considered from a spatial perspective for the development of a business park?

- What can be an adapted system of indicators for the transformation of the existing parks in eco-industrial parks (hereinafter EIPs), taking also into account the international EIPs framework?

- Last but not least, how can the above system of indicators also be applied on a national and local level in relation to the existing evidence?

To answer the above questions, the research draws on several methodological steps.

Step 1 includes (a) an inventory of realized examples of business parks from the international experience and (b) a review of the relevant literature.

Step 2 includes (a) the development of the research question, (b) the interpretation of the effects of the Greek legislation on the development of the so-called "Organized Receptors of Manufacturing and Business Activities" (OYMEDs), and (c) a draft of guiding principles for increasing the attractiveness of business parks; 
Step 3 includes the proposal of a system of indicators that should be taken into account for transforming existing parks into eco-industrial parks (EIPs) and monitoring their multiple performances (park management-related, social, economic, and environmental).

Step 4 includes (a) further analysis of the Greek case based on existing data, (b) an attempt to apply the above system of indicators on a country and local level by the examination of a single business park located in the peri-urban area of the city of Kozani in the Western Macedonia region of Greece, and (c) identification of gaps and policy recommendations. Schematically, our methodology is presented in Figure 1.

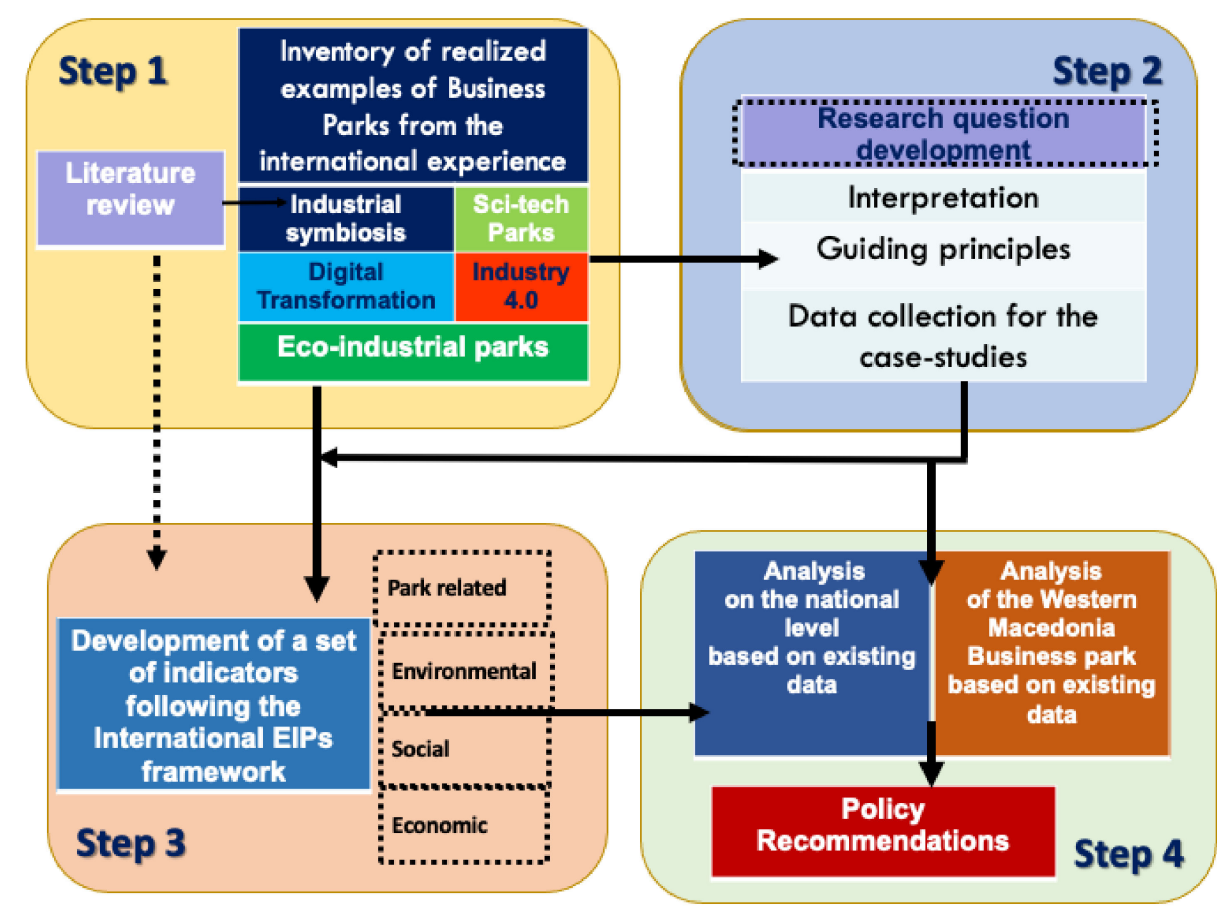

Figure 1. The research methodology. Source: Own elaboration by authors.

Our data sources for Steps 2, 3, and 4 were the following: (a) the Greek Ministry of Environment and Energy, responsible also for spatial planning policy; (b) the Secretariat General of Industry (Greek Ministry of Development); (c) several "Environmental Impact Assessment" studies conducted by private consultancies for certain business parks; (d) the international framework relevant to eco-industrial parks (EIPs).

\subsection{The Spatial Model of the Development of Industrial Activities in Greece}

The configuration of the existing spatial model for the development of industrial activities in Greece is considerably influenced by the peculiar-and very particular to Greece-established practice of urban development and construction outside the approved urban plans [36,37]. In other words, industrial development in Greece has typically evolved using an ad hoc location of manufacturing facilities, with no overall planning and arrangements based on land-use plans [38,39]. Delays in introducing an integrated territorial development have significantly impacted the sustainable development of productive activities and, to some extent, this is still ongoing. The first integrated "Regional Spatial Planning Frameworks" (see Table 1) were adopted in 2003 (with some of them undergoing revision between 2018 and 2019), whilst the sectorial Special Spatial Planning Framework for Industry (hereinafter SSPFI) [39] was adopted in 2009 (see Figure 2), aiming at updating spatial planning related to industrial location and adapting it to the modern requirements of sustainable development $[40,41]$. 
Table 1. The Greek spatial planning system structure.

\begin{tabular}{|c|c|c|c|}
\hline \multirow{2}{*}{$\begin{array}{l}\text { Visionary } \\
\text { strategic plan of } \\
\text { nonbinding } \\
\text { character }\end{array}$} & $\begin{array}{l}\text { National Strategy } \\
\text { for Spatial } \\
\text { Planning }\end{array}$ & $\begin{array}{l}\text { Indicative directions of spatial } \\
\text { organization; medium- and long-term } \\
\text { territorial development goals; } \\
\text { coordination of policies with territorial } \\
\text { impact; includes the national strategy } \\
\text { for the marine space. }\end{array}$ & \multirow[t]{2}{*}{$\begin{array}{c}\text { National } \\
\text { level }\end{array}$} \\
\hline & $\begin{array}{l}\text { Special Spatial } \\
\text { Planning } \\
\text { Frameworks }\end{array}$ & $\begin{array}{l}\text { Strategic directions for the spatial } \\
\text { structure of the housing network, } \\
\text { economic sectors/industries of national } \\
\text { importance, land policy, protection of } \\
\text { cultural and natural landscape, and } \\
\text { development and organization of areas } \\
\text { with special value (spatial, } \\
\text { environmental, development, etc.). }\end{array}$ & \\
\hline \multirow{2}{*}{$\begin{array}{l}\text { Spatial and } \\
\text { regional plans } \\
\text { (guideline and } \\
\text { occasionally } \\
\text { regulatory plans) }\end{array}$} & $\begin{array}{c}\text { Regional Spatial } \\
\text { Planning } \\
\text { Frameworks }\end{array}$ & $\begin{array}{l}\text { Directions (and, if necessary, } \\
\text { regulations) for integrated territorial } \\
\text { development on the regional level; } \\
\text { especially for the Attica region, the new } \\
\text { Athens-Attica Regulatory Framework } \\
\text { (Law } 4277 / 2014 \text { ) is already in place. }\end{array}$ & \multirow[t]{2}{*}{$\begin{array}{l}\text { Regional } \\
\text { level }\end{array}$} \\
\hline & $\begin{array}{c}\text { Maritime Spatial } \\
\text { Planning } \\
\text { Frameworks }\end{array}$ & $\begin{array}{l}\text { Directions of spatial development and } \\
\text { organization for the allocation of } \\
\text { existing and new emerging maritime } \\
\text { activities and uses (based on the } \\
\text { subdivisions of marine space defined by } \\
\text { the National spatial strategy of marine } \\
\text { space, the latter being part of the } \\
\text { National Spatial Planning Strategy). }\end{array}$ & \\
\hline \multirow{3}{*}{$\begin{array}{l}\text { Urban plans of } \\
\text { regulatory } \\
\text { character }\end{array}$} & $\begin{array}{l}\text { Local Spatial } \\
\text { Plans }\end{array}$ & $\begin{array}{l}\text { Defined at the level of one or more } \\
\text { municipal units (within one or more } \\
\text { local authorities), the model of spatial } \\
\text { organization and development, land } \\
\text { uses, building rules and restrictions, and } \\
\text { any other measures or } \\
\text { spatial restrictions. }\end{array}$ & \multirow{3}{*}{$\begin{array}{l}\text { Local } \\
\text { level }\end{array}$} \\
\hline & $\begin{array}{l}\text { Special Urban } \\
\text { Plans }\end{array}$ & $\begin{array}{l}\text { Defined in areas regardless of } \\
\text { administrative boundaries, in order to } \\
\text { set land uses, general terms and } \\
\text { restrictions, and any other measure or } \\
\text { rule, to act as a host for projects and } \\
\text { programs of strategic importance (and } \\
\text { needs for special regulations). }\end{array}$ & \\
\hline & $\begin{array}{l}\text { Implementation } \\
\text { Urban Plans }\end{array}$ & $\begin{array}{l}\text { Specification of rules and regulations of } \\
\text { local and special plans (e.g., in terms of } \\
\text { uses and building rules); accurate } \\
\text { definition of multi-use areas, public } \\
\text { utilities, and buildable spaces; exact } \\
\text { allocation of infrastructure networks. }\end{array}$ & \\
\hline
\end{tabular}




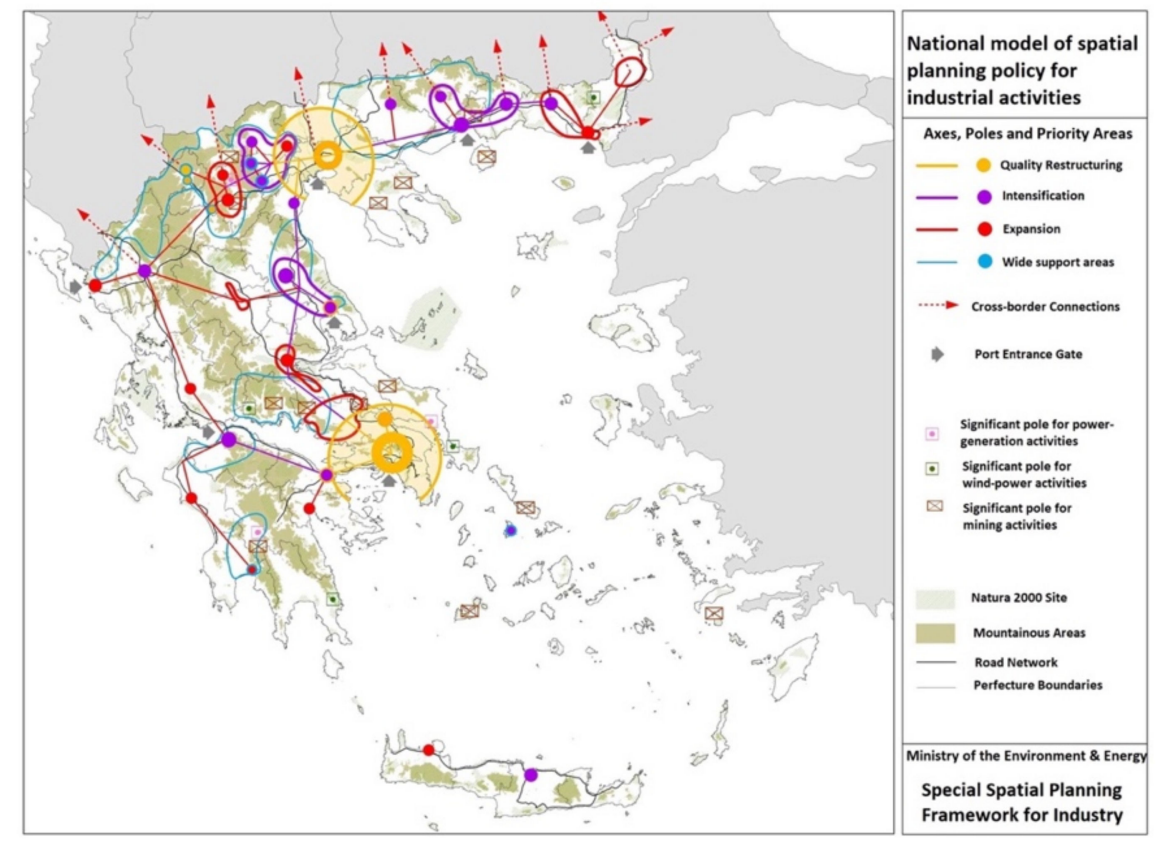

Figure 2. Special Spatial Planning Framework for Industry (SSPFI), Greece. Source: Greek Government Gazette 151/ААП/2009 [39].

Specifically, the SSPFI [39] identifies in detail the weaknesses and problems brought about by the unregulated and unplanned development of manufacturing activities, placing particular emphasis on organized location, which is clearly a shift in relation to the past practices. The advantages deriving from the concentration of productive activities in "organized receptors" being subject to appropriate location in areas planned in advance with compatible land uses and development rules are currently under investigation by relevant evolving research. The same goes for the specific organizational and spatial conditions to support this type of development.

In this context, the present paper can be seen as a contribution to the scientific discussion regarding the modern spatial and organizational needs and conditions for the development of new or the transformation of existing receptors of productive activities. It takes into account both the forces that have defined spatial standards for the organization of manufacturing activities and the current institutional settings for spatial planning. Particular account is taken of developments such as industrial symbiosis and the circular economy [43-45], eco-industry and eco-innovation [46-48], green and digital transition (Industry 4.0) [49-52], climate neutrality [53], and the new European Union (EU) Industrial Strategy [54]. This huge arsenal is rapidly transforming the framework and rules under which contemporary integrated spatial and development planning for productive activities is specified and subsequently implemented [55].

According to the above, Greek spatial planning needs to be immediately adapted to support the observed transformations, while the institutional framework governing business parks, viewed as a modern land policy instrument for the development of productive activities [56], must be timely adjusted to attain the objective set. Central to the successful implementation of integrated planning seem to be the applied urban policy and the spatial governance systems that act as catalysts for creativity and innovation, decisively influencing decision-making and, ultimately, the implementation of spatial tools [57]. Location remains, therefore, the key criterion for the viability of an enterprise [58-60], as well as for shaping economic and social conditions in the local community and for the strategic development of the wider region, in which the business is established [61-65]. 


\subsection{Examples of Business Parks from the International Experience}

The development of modern BPs emphasizes the creation of knowledge and innovation ecosystems, distinguished for their multifunctional and integrated urban planning character [66]. In modern urban policies, the decision on the site where a business park is implanted is a complex one and depends largely on the interactions it develops with the wider urban structure. Although the site still matters, the business park is seen as part of the overall ecosystem and not as an isolated "growth pole", as was the case in the past [67]. Different critical factors are currently taken into account when investigating a site for the development of a receptor, as discussed below.

A series of typical examples of modern business parks either lately established or renovated to integrate latest trends [20,68] are the following: (a) the Research Triangle Park in North Carolina, United States of America (USA), which is one of the largest research parks in the United States and a leading global center for innovation [69]; (b) the 22@District in Barcelona, an innovation center attracting significant investments and substantially contributing to the upgrading of the local urban area [70]; (c) the Rotterdam Harbor, which is evolving into a business park with highly developed industrial symbiosis activities developed in the port of Rotterdam [71]; (d) the "Deux Synthe" and the Pomacle-Bazancourt Parks in France (near Dunkirk and Rennes, respectively), transformed into eco-industrial parks, with a particularly low carbon footprint and relying on the use of renewable energy sources (RES) [72,73]; (e) the "Porto Digital" (Digital Port) in the city of Recife, in northeast Brazil, significantly specializing in growth, currently recognized as one of the most important innovation areas in the country [74]. On the basis of these examples, several elements are emerging as common ground in the context of current industrial policies (both spatial and nonspatial), yet with a significant impact on the overall urban ecosystem.

First comes the strategic location and the requirements for urban or nonurban functions that are usually consistent with the needs of businesses and employees (travel time, availability of a research center/university, travel time of employees, etc.). Generally, there is an availability of a skilled workforce and of people with appropriate knowledge able to meet the needs of the park's development and of the operation of the businesses to be established in it. Furthermore, there are collaborative mechanisms/schemes being developed with the existing productive fabric. In this respect, it is particularly examined whether similar companies exist for cooperation and whether the local and/or central government is willing to cooperate with industry. Moreover, what counts is the existing level of infrastructure and the planning for future infrastructure and networks. These vary from waste management, telecommunications, interconnectivity, and accessibility networks, such as access to air travel hubs, ports, road, and rail connections, to specific regulatory factors such as building terms and restrictions, real estate market and business establishment costs, availability and types of incentives, provision of public utilities, environment, and quality of life.

\section{Results}

\subsection{The Failure over Time to Create Business Parks in Greece}

Industrial production in Greece recorded its best-ever performance after World War II and, in particular, during the 1950s and the 1960s. However, until the beginning of 1970s, economic activities proliferated in an arbitrary manner, with the country's economic growth being the sole determination. Industrial facilities were established in a spatially unregulated manner and without adequate integration of the environmental dimension. Thus, with the exception of some "pockets" of industrial concentration, developed or not on the basis of relevant legislation, the Greek industry for the most part appears to be dispersed throughout the Greek territory, with trends of concentration around the major urban centers (primarily Athens and Thessaloniki). Indeed, the chapter on industry of the Athens Master Plan developed in 1976 by Doxiadis Associates on behalf of the Ministry of Coordination, states that 
"[ ... ] the lack of an organized system of industrial zones has led and continues to lead to the creation of large industries in residential, holiday, historical, and other areas that are valuable for the smooth functioning of the Capital [ ... ]" [75].

During the 1960s, the Greek capital region presented a high attractiveness for human resources and economic activities to the detriment of other, less accessible regions of the country. During the same period, the Patras-Athens-Larissa-Volos-Thessaloniki road axis began to develop. To resolve the issue, the State assumed an interventionist role and introduced incentives for the relocation of industry away from Attica and Thessaloniki. Precisely, in 1965, the first Greek law for the establishment of industrial areas (the so-called VIPE in Greek) was approved, and the first "VIPEs" were established in Thessaloniki, Volos, Heraklion, Patras, and Kavala. Subsequently, during the next 20 years (1970 to 1990), a substantial effort was made to enact legislation on industrial land use in Greece. During that period, special regulations were issued (i.e., the presidential decree 84/84), aimed at moving industry away from the Greek capital, followed by the introduction of the general town plans (GTPs), while measures to protect the environment were also promoted, such as the classification of industrial activities based on the type of nuisance they caused. Despite relevant state policies at the time, the regional problem remained unsolved. The persistent effort to dissuade industrial businesses from launching new installations in the major urban agglomerations (Athens and Thessaloniki) led to the continuation of a well-known practice: the establishment of informal industrial concentrations (IICs) at a short distance from the country's major urban centers.

The period from 1990 to 2020 witnessed a gradual decline in investments, which culminated in the start of the 2009 economic crisis. These new circumstances led to structural changes in the economy and beyond. Many institutional changes were promoted during this period, through improvements in the institutional framework for business parks, enabling private entities to organize themselves in a business park or in an informal industrial concentration (ICC). This same period saw the introduction (in 2009) of the Special Spatial Planning Framework for Industry (SSPFI), intended to serve as a strategic planning document at the national level and representing a very positive step for the organization of industrial activities in Greece. Its guidelines were further adopted later on by the revised integrated "Regional Spatial Planning Frameworks" introduced in the period from 2018 to 2020 [75].

\subsection{The Role of Business Parks in the Modern Greek Business Environment}

According to Foundation for Economic and Industrial Research (IOVE) data [76], the total impact of the activity in industrial areas on the domestic annual gross production value currently stands at 17.5 billion EUR. In addition, production in industrial areas has strong indirect effects on the added value created by the Greek economy, mainly through the stimulation of economic activity in tertiary sector activities such as financial and consulting services (accountants, lawyers, engineers, and other professionals), real estate trade and management, and agricultural production. At a regional level, activity in the Hellenic Industrial Development Bank (ETBA S.A) industrial areas, has a strong economic impact in several regions, namely, Eastern Macedonia and Thrace, Epirus, and Central Macedonia, and it makes a significant contribution to the local economies in both the regions of Crete and Western Greece.

Specifically, the activities of production units in industrial areas and their impact account for a total of $17 \%$ of the gross value produced in Eastern Macedonia and Thrace (corresponding to a total contribution of nearly 2.1 billion EUR). The activity of industrial areas accounts for about $16 \%$ of the gross value produced in Epirus, $15 \%$ of the gross value produced in Crete, $13 \%$ of the gross value produced in Central Macedonia, and about $12 \%$ of the gross value produced in Western Greece.

In absolute figures, the activities of production units in industrial areas have a particularly strong economic impact in Central Macedonia, contributing 5.7 billion EUR in total to the region's gross production value. According to the abovementioned IOVE report [76], 
it is also worth noting that activities in industrial areas have a significant economic impact also in Attica (Athens region), despite the fact that there are no industrial areas in the country's economic center. The overall effect of activity in industrial areas on the gross production value in Attica, amounting to 1.7 billion EUR, is entirely due to the indirect and induced effects of production in industrial areas.

Noteworthy is also the contribution of the production units in industrial areas to regional employment. Their activities directly account for nearly 3\% of employment in the regions of Epirus and Eastern Macedonia, and Thrace (5.9 thousand jobs) and $2 \%$ of employment in the regions of Central Macedonia (13.4 thousand jobs) and Crete (5.2 thousand jobs). The overall impact of the activity in the ETVA industrial areas on employment in these regions is, however, much stronger. Indicatively, industrial activity accounts for a total of nearly 14\% of employment in Epirus (nearly 15.9 thousand full-time jobs) and Eastern Macedonia and Thrace (27.8 thousand jobs), 13\% of employment in Crete (31.6 thousand jobs), and 12\% of employment in Central Macedonia (78.9 thousand jobs). The regional effects of the activity of industrial areas on job creation is particularly significant, taking into account the fact that enterprises operating in industrial areas provide strong support to employment in regions severely affected by the economic crisis of recent years [76]. In summary, in the country's 13 regions, the following units have been developed: (a) 63 OYMED areas covering $78.381 \mathrm{~km}^{2}$ in total (effectively, 58 OYMEDs); (b) 415 plots of land for industrial use, covering $238.390 \mathrm{~km}^{2}$ in total; (c) 66 plots of land for wholesale trade use, covering $49.306 \mathrm{~km}^{2}$ in total, as shown in detail in the Table 2, below [38].

Table 2. Spatial allocation and characteristics of Organized Receptors of Manufacturing and Business Activities (OYMEDs) in the Greek territory.

\begin{tabular}{ccccccc}
\hline \multirow{2}{*}{ Region } & \multicolumn{2}{c}{$\begin{array}{c}\text { OYMEDs (Separate } \\
\text { OYMED Areas) }\end{array}$} & \multicolumn{2}{c}{ Industrial Uses } & \multicolumn{2}{c}{ Wholesale Trade } \\
\cline { 2 - 7 } & Number & $\begin{array}{c}\text { Area } \\
\left(\mathbf{k m}^{\mathbf{2}} \mathbf{n}\right.\end{array}$ & Number & $\begin{array}{c}\text { Area } \\
\mathbf{( k m}^{\mathbf{2}} \mathbf{n}\end{array}$ & Number & $\begin{array}{c}\text { Area } \\
\mathbf{k k m}^{\mathbf{2}} \mathbf{n}\end{array}$ \\
\hline $\begin{array}{c}\text { Eastern Macedonia } \\
\text { and Thrace }\end{array}$ & $8(8)$ & 13.481 & 8 & 5.783 & 1 & 0.378 \\
\hline Central Macedonia & $11(1)$ & 19.383 & 86 & 85.938 & 19 & 28.774 \\
\hline Western Macedonia & $5(50$ & 2.642 & 7 & 5.743 & 0 & 0.0 \\
\hline Epirus & $3(3)$ & 4.289 & 9 & 5.504 & 1 & 0.253 \\
\hline Thessaly & $6(7)$ & 10.214 & 48 & 14.889 & 8 & 3.280 \\
\hline Ionian Islands & $1(1)$ & 0.123 & 0 & 0.00 & 0 & 0.0 \\
\hline Western Greece & $3(3)$ & 6.723 & 7 & 2.143 & 1 & 0.307 \\
\hline Sterea & $5(7)$ & 8.160 & 68 & 45.503 & 6 & 1.829 \\
\hline Attica & $5(7)$ & 5.916 & 3625 & 46.147 & 20 & 11.589 \\
\hline Peloponnese & $3(3)$ & 3.625 & 20 & 6.915 & 3 & 0.629 \\
\hline North Aegean & $0(0)$ & 0.0 & 7 & 4.461 & 2 & 0.996 \\
\hline South Aegean & $1(1)$ & 0.017 & 14 & 1.476 & 1 & 0.004 \\
\hline Crete & $7(7)$ & 3.808 & 38 & 13.888 & 4 & 1.267 \\
\hline Total & $58(63)$ & 78.381 & 415 & 238.390 & 66 & 49.306 \\
\hline
\end{tabular}

Source: Ministry of Development and Investments, 2018 [38].

It is noteworthy that, through the revised Regional Spatial Planning Frameworks, there was a significant change in the promoted model of industry-based territorial development. In particular, the number of proposed (from 2018 to date) new business parks is particularly high that is more than double the number of parks built from 1965 to date (see Figure 3). An important factor supporting the whole project is the recent spatial and urban planning law (Law 4759/2020) [42], which limits the unplanned developments (in areas with land-use plans) and fosters — through spatial incentives—-the attractiveness of business 
parks (new building rules, advantages for energy-efficient buildings, and acceleration of implementation plans).

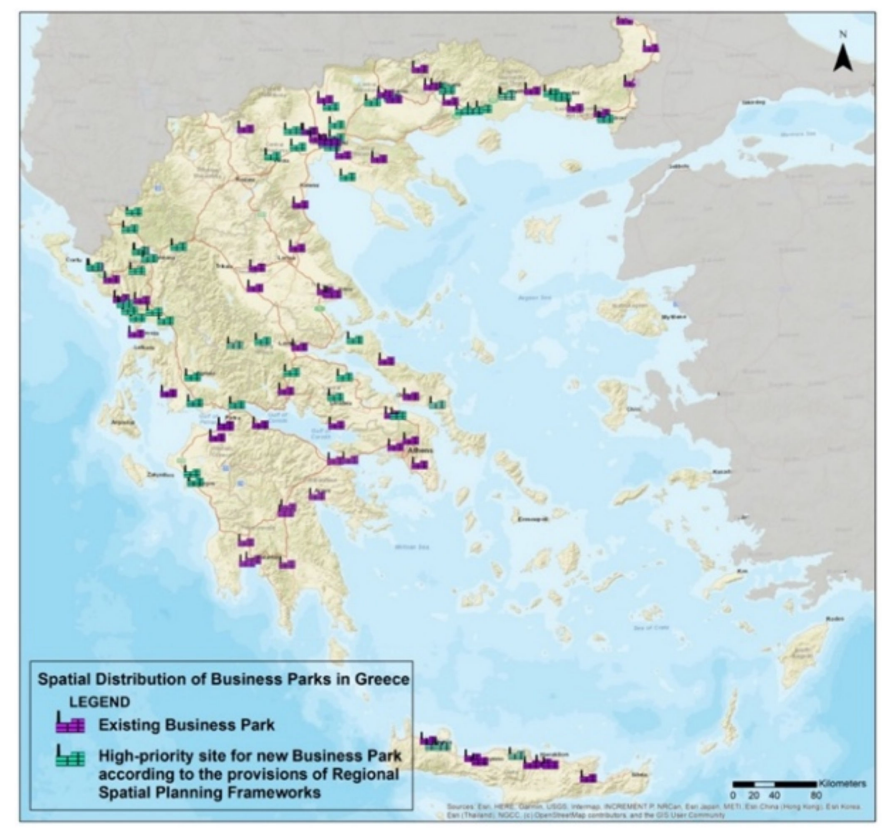

Figure 3. Spatial distribution of business parks in Greece. Source: Own elaboration based on Regional Spatial Planning Frameworks data [77-85].

Of course, the share of each region in the total gross value added (GVA) of the manufacturing sector is not correlated to the size of industrial land plots within organized receptors; in other words, production activity does not appear to be correlated with the existence of business parks.

Although, internationally, the creation of BPs is an established practice for attracting investment, supporting industry, and ultimately protecting the environment, Greece is found to be considerably lagging behind in this respect, for reasons that concern both the State and the businesses. Greek BPs, due to several location, development, and operationrelated defects, were apparently unable to convince businesses of the substantial benefits and the facilities they offer. Above all, however, it is the possibility provided by the institutional framework for construction outside the approved zoning plans that acts as a deterrent to the establishment of businesses inside BPs. Businesses usually consider that the establishment of their activities outside the parks is rather advantageous due to low land prices [77].

A comprehensive analysis of existing industrial areas at a national level, concluded that Greece does not have a central mechanism for recording and monitoring key development and management attributes of organized receptors. The data are incomplete and fragmented, and there are several shortcomings, especially in recording and evaluating modern considerations such as energy and water efficiency, waste disposal, reuse and recycling, harassment response, community outreach, and local job generation.

Data were either identified by the authors in the context of the present study (secondary data sources such as the Hellenic Statistical Authority (ELSTAT in Greek), Google Earth, and the updated Regional Spatial Planning Frameworks) [77-85] or found in collaboration with the management bodies of the business parks (unpublished data). They concern mainly park location, management, and spatial characteristics. According to the research carried out in 27 organized receptors (see Figure 4, below), the following elements were identified (see also Tables 3-5):

- $56 \%$ of industrial parks are up to $10 \mathrm{~km}$ away from urban centers,

- $\quad 52 \%$ are up to $10 \mathrm{~km}$ away from highways, 
- $\quad 41 \%$ are more than $20 \mathrm{~km}$ away from railway stations,

- $\quad 78 \%$ are more than $20 \mathrm{~km}$ away from airports,

- $\quad 59 \%$ are more than $20 \mathrm{~km}$ away from ports,

- $\quad 37 \%$ are integrated into a region with national borders without significant transport and transit infrastructure,

- $\quad 52 \%$ are located in regions that are isolated from abstained multimodal transport infrastructure,

- all receptors are located in regions with good access to training/research/innovation centers,

- $\quad 14 \%$ have industrial uses in more than $70 \%$ of the available space,

- $\quad 50 \%$ have open (green) space between $10 \%$ and $20 \%$ of the available space,

- $\quad 71 \%$ have roads and other common facilities between $10 \%$ and $20 \%$ of the available space.

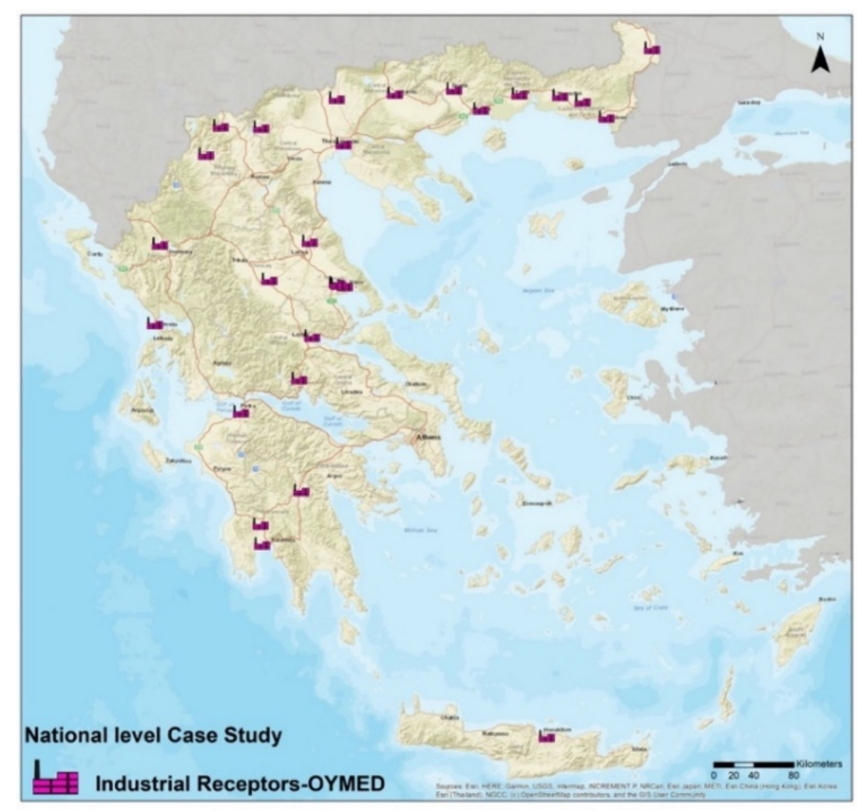

Figure 4. National-level case study of 27 business parks (OYMEDs). Source: Own elaboration by authors [77-85].

Table 3. Proximity analysis (\%) of 27 organized receptors in Greece.

\begin{tabular}{cccccc}
\hline $\begin{array}{c}\text { Distance } \\
(\mathbf{k m})\end{array}$ & $\begin{array}{c}\text { From Urban } \\
\text { Center }\end{array}$ & $\begin{array}{c}\text { From } \\
\text { HIGHWAY }\end{array}$ & $\begin{array}{c}\text { From } \\
\text { Railway } \\
\text { Station }\end{array}$ & $\begin{array}{c}\text { From } \\
\text { Airport }\end{array}$ & From Port \\
\hline$<10$ & $56 \%$ & $52 \%$ & $37 \%$ & $19 \%$ & $22 \%$ \\
\hline $10-20$ & $33 \%$ & $4 \%$ & $22 \%$ & $4 \%$ & $19 \%$ \\
\hline$>20$ & $11 \%$ & $44 \%$ & $41 \%$ & $78 \%$ & $59 \%$ \\
\hline
\end{tabular}

Source: Own elaboration. Based on data from Google Earth, the Hellenic Statistical Authority (ELSTAT), and Regional Spatial Planning Frameworks [77-85].

Table 4. Interregional analysis (\%) of 27 organized receptors.

\begin{tabular}{|c|c|c|c|c|}
\hline Cross-border character & $\begin{array}{l}\text { Integration into a } \\
\text { region with } \\
\text { national borders } \\
\text { and important } \\
\text { transport and } \\
\text { transit } \\
\text { infrastructure such } \\
\text { as ports of entry }\end{array}$ & $\begin{array}{l}\text { Integration into a } \\
\text { region with } \\
\text { national borders } \\
\text { without significant } \\
\text { transport and } \\
\text { transit } \\
\text { infrastructure }\end{array}$ & $\begin{array}{l}\text { Integration into an } \\
\text { inland or island } \\
\text { region with } \\
\text { significant } \\
\text { transport and } \\
\text { transit } \\
\text { infrastructure }\end{array}$ & $\mathrm{N} / \mathrm{A}$ \\
\hline & $7 \%$ & $37 \%$ & $30 \%$ & $26 \%$ \\
\hline
\end{tabular}


Table 4. Cont.

\begin{tabular}{|c|c|c|c|c|}
\hline $\begin{array}{l}\text { Combined/multimodal } \\
\text { transport hub }\end{array}$ & $\begin{array}{l}\text { Integration into a } \\
\text { region with } \\
\text { highway (existing } \\
\text { or under } \\
\text { construction), } \\
\text { airport, port, and } \\
\text { railway station }\end{array}$ & $\begin{array}{l}\text { Integration into a } \\
\text { region with } \\
\text { highway (existing } \\
\text { or under } \\
\text { construction) and } 2 \\
\text { of the following: } \\
\text { airport, port, or } \\
\text { train station }\end{array}$ & $\begin{array}{l}\text { Integration into a } \\
\text { region with } \\
\text { highway (existing } \\
\text { or under } \\
\text { construction) and } 1 \\
\text { of the following: } \\
\text { airport, port, or } \\
\text { train station }\end{array}$ & $\mathrm{N} / \mathrm{A}$ \\
\hline & $4 \%$ & $22 \%$ & $22 \%$ & $52 \%$ \\
\hline
\end{tabular}

Source: Own elaboration. Based on data from Google Earth and Regional Spatial Planning Frameworks [77-85]. N/A, not applicable.

Table 5. Land-use commitment (\%) of 27 organized receptors.

\begin{tabular}{cccc}
\hline \multirow{2}{*}{ Industrial } & $<70 \%$ of total land & $70-75 \%$ of total land & $>75 \%$ of total land \\
\cline { 2 - 4 } & $50 \%$ & $36 \%$ & $14 \%$ \\
\hline Open space (green) & $<10 \%$ of total land & $10-20 \%$ of total land & $>20 \%$ of total land \\
\cline { 2 - 4 } & $32 \%$ & $50 \%$ & $18 \%$ \\
\hline $\begin{array}{c}\text { Roads and other } \\
\text { common facilities }\end{array}$ & $<10 \%$ of total land & $10-20 \%$ of total land & $>20 \%$ of total land \\
\cline { 2 - 4 } & $7 \%$ & $71 \%$ & $21 \%$ \\
\hline
\end{tabular}

Source: Own elaboration. Based on data from Google Earth and implementation urban plans of organized receptors [38].

\subsection{Modern Influences on the Formulation of Modern Spatial Policies: The Role of Business Parks}

The developments taking place in European and national policies on, among others, regional and urban development, research and innovation, business and industry, the environment, and the circular economy, have a horizontal impact on spatial and development policies, which they inevitably transform. According to the recent study by the United Nations Industrial Development Organization [56], the most modern forms of organized location of manufacturing activities require the integration of environment-friendly processes, which differ significantly from those of the past.

Thus, modern industrial parks require a greater degree of flexibility in terms of location and licensing, as they aim to serve modern development and environmental purposes. Precisely, this means supporting the implementation of green growth through waste recycling, efficiency, and rational use of resources, while at the same time improving the economic cohesion and competitiveness of production centers, together with the wellbeing of workers and the prosperity of the areas around them.

According to the International Guidelines for Industrial Parks [56] study, modern challenges concern in particular the following: (1) modern urban planning and urban policies-urban centers seem to play an important role in supporting business areas. In this context, it is observed that areas adjacent to business parks present increased needs for new urban functions such as housing, medical care, and education, while the development of commercial businesses near industrial parks is quite frequent, indicating that these areas acquire urban economic and social characteristics [56]; (2) green growth and the circular economy-environmental impacts are becoming an increasingly important factor in decision-making. Moreover, there is currently a strong emphasis on how to combine green growth with spatial planning initiatives to develop business parks. In addition, in order to limit environmental impacts and ensure productivity in places with limited resources, governments and businesses are striving to increase resource efficiency and implement cleaner production practices. Lastly, the growing demand for environmental technologies that business parks are able to provide to their businesses is equally important; (3) digital transformation and Industry 4.0-the technologies related to Industry 4.0 are expected to further increase the importance of business parks, as they will intensify the reorganization of global value chains, especially through the restructuring of the investments made in places where the local workforce level of know-how is the highest possible. 
In this context, the smart solutions offered by a modern industrial park are expected to make a decisive contribution - together with qualified human resources- to more effective support of innovative technologies; (4) legal certainty and facilities for attracting foreign direct investment-since the early 1990s, there has been a sharp increase in the number of industrial parks around the world, especially in industrial and emerging economies. Maintaining competitiveness between countries, as areas of foreign direct investment, is mostly due to business parks, because of the short licensing procedures and the legal certainty they offer. Furthermore, the industrial parks of the future will have high-quality infrastructure and services, in order to better meet the ever-increasing demands of businesses.

Following the above, it is evident that spatial planning and the spatial and urban plans currently in place, as well as the corresponding policies on the development and organization of productive activities, must be broadly reformed in order to support new trends. Business parks in Greece, instead of being one of the key tools for supporting productive investments in the country, have been rather deficient over time. Yet, to the extent to which the promoted sustainable industrial development is placed at the heart of the green transition, contemporary spatial planning policies should take this into account and promote the development of fully modernized business parks.

\subsection{Designing a Set of Indicators to Assess and Monitor the Transformation of the Existing Organized Industrial Receptors into Modern Types of Developments (Such as BPs and EIPS)}

According to the directions of SSPFI [39] as well as the business plan for the development of business parks in the Greek territory [38], the existing "organized receptors for manufacturing and business activities" (OYMEDs), which were enacted between 1970 and 2000, need to be transformed into modern types of developments such as business parks (Official Gazette 143/A/2011). The same requirement applies to new developments in order to have a site and operation permit. However, from 2011 onward, other forms of organized developments emerged on the international scene. Eco-industrial parks (hereinafter EIPs) $[43,46,48]$ currently play a key role in the future development of the industrial sector $[66,72,86]$. Therefore, there is a need to modernize the existing criteria and indicators used to develop and measure the performance of organized receptors, not only on the basis of new provisions of the Greek relevant law, but also on the basis of the emerging trends at European and international level.

Indicators are a recognized tool for assessing and monitoring progress toward sustainable development. The synthesis of a system of indicators may be a guiding tool for realizing a certain vision and for designing the appropriate strategies and corresponding measures. The proposed system of indicators is inspired by the international framework for eco-industrial parks [86], the Strategic Spatial Planning for Industry in Greece [39], the business plan for the development of business parks in the Greek territory [38], and other recent studies [43,46-48,66,72,86]. Four key dimensions are examined: site (park location and management), economic, environmental, and social (see Table 6).

The construction of an integrated framework of indicators, based on the international framework, is adapted to the Greek particularities (geographic, business-related, etc.) and to the past experience regarding the negative impacts of industrial parks on neighboring areas. It is considered necessary for the protection of the environment, the improvement of infrastructure, the strengthening of business opportunities and employment, the improvement of the competitiveness of established enterprises, and the quality of life of residents in nearby areas. It can also allow the performance monitoring of the BPs and the possibility of converting them from simple BPs to eco-industrial parks aiming to foster their attractiveness and prepare the industrial sector to meet the Green Deal [87] objectives by 2050 . 
Table 6. A set of indicators to assess and monitor the transformation of the existing business parks into modern types of developments (business parks and eco-industrial parks).

\begin{tabular}{|c|c|c|c|}
\hline \multicolumn{4}{|c|}{ Environmental Indicators } \\
\hline Topic & $\begin{array}{l}\text { Sub-Topic/Sub- } \\
\text { Category }\end{array}$ & Description & Indicator \\
\hline \multirow[b]{3}{*}{ Energy } & Energy consumption & $\begin{array}{l}\text { Metering and } \\
\text { monitoring systems in } \\
\text { place to measure } \\
\text { energy consumption at } \\
\text { both the park and the } \\
\text { firm levels. }\end{array}$ & $\begin{array}{l}\text { Percentage of } \\
\text { combined park- and } \\
\text { firm-related energy } \\
\text { consumption. }\end{array}$ \\
\hline & $\begin{array}{l}\text { Renewable and } \\
\text { clean energy }\end{array}$ & $\begin{array}{l}\text { Leverages renewable } \\
\text { energy sources, with } \\
\text { plans to increase } \\
\text { contribution for } \\
\text { shared services. }\end{array}$ & $\begin{array}{c}\text { Ratio of renewable } \\
\text { energy to park over } \\
\text { national average }(\%) .\end{array}$ \\
\hline & Energy efficiency & $\begin{array}{c}\text { Identification of energy } \\
\text { efficiency } \\
\text { opportunities, } \\
\text { optimization of energy } \\
\text { use, and reduction in } \\
\text { greenhouse gas (GHG) } \\
\text { emissions. } \\
\text { Park management } \\
\text { entity sets ambitious } \\
\text { (beyond industry } \\
\text { norms) maximum } \\
\text { carbon intensity targets } \\
\text { (maximum kilograms } \\
\text { of carbon dioxide } \\
\text { equivalent). }\end{array}$ & $\begin{array}{l}\mathrm{kg} \mathrm{CO} 2 \mathrm{eq} / \text { kilowatt } \\
\text { hour (kWh) for the } \\
\text { park and its residents. } \\
\text { Targets should be } \\
\text { established for the } \\
\text { short, medium, and } \\
\text { long term. }\end{array}$ \\
\hline \multirow[t]{3}{*}{ Water } & Water consumption & $\begin{array}{l}\text { Mechanism to monitor } \\
\text { water consumption } \\
\text { across the park and } \\
\text { ensure demand } \\
\text { management practices } \\
\text { in case of water stress. } \\
\text { Extraction from water } \\
\text { sources (such as rivers } \\
\text { and groundwater } \\
\text { sources) must occur at } \\
\text { sustainable levels. }\end{array}$ & $\begin{array}{c}\text { Ratio of treated } \\
\text { wastewater to total } \\
\text { wastewater }(\%) .\end{array}$ \\
\hline & Water treatment & $\begin{array}{l}\text { Provisions in place to } \\
\text { appropriately treat, } \\
\text { recycle, and reuse } \\
\text { treated wastewater. }\end{array}$ & $\begin{array}{c}\text { Ratio of treated } \\
\text { wastewater to total } \\
\text { wastewater }(\%) .\end{array}$ \\
\hline & $\begin{array}{l}\text { Water efficiency, reuse, } \\
\text { and recycling. }\end{array}$ & $\begin{array}{c}\text { System in place to } \\
\text { increase water savings } \\
\text { and reuse. }\end{array}$ & $\begin{array}{l}\text { Ratio of water reused } \\
\text { to total water } \\
\text { consumed }(\%)\end{array}$ \\
\hline \multirow{3}{*}{$\begin{array}{l}\text { Waste and } \\
\text { material } \\
\text { use }\end{array}$} & $\begin{array}{c}\text { Waste/byproduct reuse } \\
\text { and recycling }\end{array}$ & $\begin{array}{l}\text { Promote reuse and } \\
\text { recycling of materials } \\
\text { by firms in the park. }\end{array}$ & $\begin{array}{l}\text { Ratio of reused solid } \\
\text { waste to total } \\
\text { waste }(\%) .\end{array}$ \\
\hline & $\begin{array}{l}\text { Dangerous and toxic } \\
\text { materials }\end{array}$ & $\begin{array}{l}\text { Reduce and avoid the } \\
\text { use of dangerous and } \\
\text { hazardous materials by } \\
\text { firms in the park. }\end{array}$ & $\begin{array}{l}\text { Proportion of firms in } \\
\text { park that appropriately } \\
\text { handle, store, transport, } \\
\text { and dispose of toxic } \\
\text { and } \\
\text { hazardous materials. }\end{array}$ \\
\hline & Waste disposal & $\begin{array}{l}\text { Unused waste } \\
\text { materials are treated } \\
\text { and disposed of in } \\
\text { proper landfills }\end{array}$ & $\begin{array}{l}\text { Ratio of waste } \\
\text { to landfill. }\end{array}$ \\
\hline
\end{tabular}


Table 6. Cont.

\begin{tabular}{|c|c|c|c|}
\hline \multicolumn{4}{|c|}{ Environmental Indicators } \\
\hline Topic & $\begin{array}{l}\text { Sub-Topic/Sub- } \\
\text { Category }\end{array}$ & Description & Indicator \\
\hline \multirow{2}{*}{$\begin{array}{l}\text { Climate } \\
\text { change and } \\
\text { the natural } \\
\text { environ- } \\
\text { ment }\end{array}$} & $\begin{array}{l}\text { Minimum proportion } \\
\text { of open space in the } \\
\text { park for the } \\
\text { maintenance of } \\
\text { environmental balance } \\
\text { (acting also as } \\
\text { compensation measure } \\
\text { for the loss caused by } \\
\text { the construction of } \\
\text { the park) }\end{array}$ & $\begin{array}{l}\text { Maintain natural areas } \\
\text { in the park. }\end{array}$ & $\begin{array}{l}\text { Ratio of open (green) } \\
\text { space to the total } \\
\text { park surface. }\end{array}$ \\
\hline & $\begin{array}{l}\text { Air, GHG emissions, } \\
\text { and pollution } \\
\text { prevention }\end{array}$ & $\begin{array}{l}\text { Firms in park having } \\
\text { strategies for pollution } \\
\text { prevention and } \\
\text { emissions reduction, to } \\
\text { improve intensity and } \\
\text { mass flow of } \\
\text { pollution/emission } \\
\text { release beyond national } \\
\text { regulations. }\end{array}$ & $\begin{array}{l}\text { Percentage of firms } \\
\text { applying relevant } \\
\text { specific strategies. }\end{array}$ \\
\hline \multicolumn{4}{|c|}{ Park Location/Management-Related Indicators } \\
\hline Topic & $\begin{array}{l}\text { Sub-topic/Sub- } \\
\text { category }\end{array}$ & Description & Indicators \\
\hline $\begin{array}{l}\text { Proximity } \\
\text { to urban } \\
\text { agglomera- } \\
\text { tions }\end{array}$ & $\begin{array}{c}\text { - Regional capitals } \\
\text { - City with population } \\
\text { over } 60,000 \text { inhabitants } \\
\text { - City with national } \\
\text { port-gateway }\end{array}$ & $\begin{array}{l}\text { Consideration and } \\
\text { evaluation of specific } \\
\text { territorial data, such as } \\
\text { proximity to cities, } \\
\text { capital regions and } \\
\text { municipalities, national } \\
\text { ports, gateways, etc., } \\
\text { and population } \\
\text { characteristics. }\end{array}$ & $\begin{array}{c}\text { Territorial data } \\
\text { (population, distance to } \\
\text { cites, etc.). }\end{array}$ \\
\hline $\begin{array}{l}\text { Financial } \\
\text { capacity }\end{array}$ & $\begin{array}{l}\text { - Regional units that } \\
\text { present percentages } \\
\text { more than } 10 \% \text { of } \\
\text { national gross value } \\
\text { added (GVA) } \\
\text { - Regional units that } \\
\text { present percentages } \\
\text { between } 2.05 \% \\
\text { and } 9.99 \% \\
\text { - Regional units that } \\
\text { present percentages } \\
\text { between } 1.05 \% \text { and } 2 \% \\
\text { - All other regional } \\
\text { units with percentages } \\
\text { between } 0 \% \text { and } 1.04 \%\end{array}$ & $\begin{array}{l}\text { Evaluation of the } \\
\text { participation of each } \\
\text { regional unit in the } \\
\text { creation of the national } \\
\text { gross value added } \\
\text { (GVA) in the year } \\
\text { preceding the } \\
\text { preparation of the } \\
\text { business plan. }\end{array}$ & $\begin{array}{c}\text { Ratio of produced GVA } \\
\text { by regional unit over } \\
\text { the national GVA. }\end{array}$ \\
\hline $\begin{array}{l}\text { Business } \\
\text { index of } \\
\text { the region } \\
\text { where the } \\
\text { business } \\
\text { park (BP) is } \\
\text { installed }\end{array}$ & $\begin{array}{l}\text { Regional units } \\
\text { presenting } \\
\text { percentages of } \\
-\quad 1 \% \text { or more } \\
-\quad 0.5-1 \% \\
-\quad 0.25-0.5 \% \\
-\quad 0-0.25 \%\end{array}$ & $\begin{array}{l}\text { Complex index, } \\
\text { composed of } 50 \% \text { of } \\
\text { the average exports of } \\
\text { the regional unit } \\
\text { during the last } 5 \text { years } \\
\text { and } 50 \% \text { of the value } \\
\text { added of the regional } \\
\text { unit in manufacturing } \\
\text { activities, the year } \\
\text { before the preparation } \\
\text { of the business plan. }\end{array}$ & Complex index. \\
\hline
\end{tabular}


Table 6. Cont.

\begin{tabular}{|c|c|c|c|}
\hline \multicolumn{4}{|c|}{ Park Location/Management-Related Indicators } \\
\hline Topic & $\begin{array}{l}\text { Sub-Topic/Sub- } \\
\text { Category }\end{array}$ & Description & Indicator \\
\hline $\begin{array}{l}\text { Demand of } \\
\text { industrial } \\
\text { land within } \\
\text { "Organized } \\
\text { receptors" }\end{array}$ & $\begin{array}{l}\text { Regional units that } \\
\text { have BPs and the } \\
\text { average annual } \\
\text { demand for industrial } \\
\text { land during the last } \\
5 \text { years is } \\
\text { - greater than } 30 \% \\
-\quad 5-30 \% \\
-\quad 2-5 \%, \\
-\quad \text { below } 2 \%\end{array}$ & $\begin{array}{l}\text { Evaluation of data } \\
\text { referring to the number } \\
\text { of industrial land plot } \\
\text { sales and to the } \\
\text { availability of } \\
\text { industrial land inside } \\
\text { the organized } \\
\text { receptors. }\end{array}$ & $\mathrm{N} / \mathrm{A}$ \\
\hline $\begin{array}{l}\text { Availability } \\
\text { of } \\
\text { industrial } \\
\text { land within } \\
\text { existing } \\
\text { organized } \\
\text { receptors" }\end{array}$ & $\begin{array}{l}\text { Regional units that } \\
\text { have organized BPs } \\
\text { and for which the } \\
\text { period of depletion of } \\
\text { industrial land (based } \\
\text { on the average annual } \\
\text { sales rate of the last } \\
\text { five years) is: } \\
\text { - less than } 10 \text { years } \\
\text { - } 10-20 \text { years } \\
\text { - 20-30 years } \\
\text { - without organized } \\
\text { receptors. }\end{array}$ & $\begin{array}{l}\text { Evaluation of data } \\
\text { referring to the } \\
\text { availability of } \\
\text { industrial land inside } \\
\text { the existing organized } \\
\text { receptors. }\end{array}$ & $\mathrm{N} / \mathrm{A}$ \\
\hline $\begin{array}{l}\text { International } \\
\text { transport } \\
\text { networks } \\
\text { and related } \\
\text { services }\end{array}$ & $\begin{array}{c}\text { Regional units } \\
\text { crossed by } \\
\text { - Highway } \\
\text { - } \quad \text { Railways stations } \\
\text { - } \text { Regional units with } \\
\text { planned highway or } \\
\text { railway } \\
\text { - Regional units that } \\
\text { do not fall into any of } \\
\text { the above three } \\
\text { categories }\end{array}$ & $\begin{array}{l}\text { Consideration of data } \\
\text { related to the } \\
\text { proximity/accessibility } \\
\text { of "organized } \\
\text { receptors" to national } \\
\text { transport networks. }\end{array}$ & $\mathrm{N} / \mathrm{A}$ \\
\hline $\begin{array}{l}\text { Cross- } \\
\text { border } \\
\text { character }\end{array}$ & $\begin{array}{l}\text { - Regional units of } \\
\text { mainland Greece } \\
\text { bordering Bulgaria and } \\
\text { Turkey crossed by } \\
\text { vertical connection } \\
\text { axes like the Egnatia } \\
\text { highway and regional } \\
\text { units where there are } \\
\text { ports / gateways to the } \\
\text { European Union (EU) } \\
\text { (e.g., Igoumenitsa) } \\
\text { - Cross-border } \\
\text { regional units of } \\
\text { mainland Greece with } \\
\text { land borders not } \\
\text { included in the } \\
\text { previous category } \\
\text { - Regional units of } \\
\text { mainland Greece and } \\
\text { island Greece which } \\
\text { have important ports } \\
\text { of communication with } \\
\text { other countries } \\
\text { - Regional units of the } \\
\text { country that do not fall } \\
\text { into any of the above } \\
\text { three categories }\end{array}$ & $\begin{array}{l}\text { Consideration of } \\
\text { cross-border } \\
\text { elaboration in terms of } \\
\text { geomorphological } \\
\text { features, existence of } \\
\text { cross-border } \\
\text { infrastructures, and } \\
\text { transport networks. }\end{array}$ & $\mathrm{N} / \mathrm{A}$ \\
\hline
\end{tabular}


Table 6. Cont.

\begin{tabular}{|c|c|c|c|}
\hline \multicolumn{4}{|c|}{ Park Location/Management-Related Indicators } \\
\hline Topic & $\begin{array}{l}\text { Sub-Topic/Sub- } \\
\text { Category }\end{array}$ & Description & Indicator \\
\hline $\begin{array}{c}\text { Service } \\
\text { from } \\
\text { natural gas } \\
\text { network }\end{array}$ & $\begin{array}{l}\text { - Regional units } \\
\text { crossed by a natural } \\
\text { gas pipeline of high or } \\
\text { medium pressure } \\
\text { - All other } \\
\text { regional units }\end{array}$ & $\begin{array}{l}\text { Consideration of the } \\
\text { existence of high- or } \\
\text { medium-pressure } \\
\text { gas pipeline. }\end{array}$ & $\mathrm{N} / \mathrm{A}$ \\
\hline $\begin{array}{l}\text { Proximity } \\
\text { to a } \\
\text { combined } \\
\text { transport } \\
\text { hub. }\end{array}$ & $\begin{array}{c}\text { - Regional units } \\
\text { crossed by a highway } \\
\text { and having an airport, } \\
\text { port, and railway } \\
\text { station } \\
\text { - Regional units } \\
\text { crossed by a highway, } \\
\text { having two out of the } \\
\text { three above kinds of } \\
\text { infrastructure (airport, } \\
\text { port, or train station) } \\
\text { - Regional units } \\
\text { crossed by a highway } \\
\text { and having an airport, } \\
\text { port, or train station } \\
\text { - Regional units that } \\
\text { do not fall into any of } \\
\text { the above three } \\
\text { categories. }\end{array}$ & $\begin{array}{l}\text { Consideration of data } \\
\text { related to the access } \\
\text { and the proximity to } \\
\text { multimodal and } \\
\text { combined transport } \\
\text { networks. Evaluation } \\
\text { of the combination of } \\
\text { the above criterion } \\
\text { "international transport } \\
\text { networks and related } \\
\text { services" with other } \\
\text { modes of } \\
\text { transportation (e.g., } \\
\text { rail, ship, or aircraft). }\end{array}$ & $\mathrm{N} / \mathrm{A}$ \\
\hline $\begin{array}{l}\text { Proximity } \\
\text { to training, } \\
\text { research, or } \\
\text { innovation } \\
\text { service } \\
\text { centers. }\end{array}$ & $\begin{array}{l}\text { - More than } 1 \mathrm{~h} \\
\text { distance } \\
\text { - Less than } 1 \mathrm{~h} \\
\text { distance }\end{array}$ & $\begin{array}{l}\text { Consideration of the } \\
\text { distance from } \\
\text { university/training } \\
\text { institutions, research } \\
\text { centers, etc. }\end{array}$ & Distance in $\mathrm{km}$. \\
\hline \multicolumn{4}{|c|}{ Social Indicators } \\
\hline Topic & $\begin{array}{l}\text { Sub-topic/Sub- } \\
\text { category }\end{array}$ & Description & Indicators \\
\hline \multirow{3}{*}{$\begin{array}{l}\text { Social man- } \\
\text { agement } \\
\text { systems }\end{array}$} & $\begin{array}{l}\text { Occupational health } \\
\text { and safety } \\
\text { management systems } \\
\text { (OH\&S) }\end{array}$ & $\begin{array}{l}\text { Firms in the BP should } \\
\text { have an OH\&S } \\
\text { management system in } \\
\text { place, to record various } \\
\text { events and keep rates } \\
\text { about events like injury, } \\
\text { occupational diseases, } \\
\text { and absenteeism, as } \\
\text { well as data on } \\
\text { work-related fatalities. }\end{array}$ & $\begin{array}{l}\text { Percentage of firms } \\
\text { applying OH\&S } \\
\text { management systems. }\end{array}$ \\
\hline & $\begin{array}{c}\text { Grievance } \\
\text { management }\end{array}$ & $\begin{array}{c}\text { A grievance } \\
\text { mechanism should be } \\
\text { in place, able to receive } \\
\text { and address internal } \\
\text { and external } \\
\text { grievances. }\end{array}$ & $\begin{array}{l}\text { Relative numbers of } \\
\text { grievances. }\end{array}$ \\
\hline & Harassment response & $\begin{array}{l}\text { Establish a mechanism } \\
\text { to prevent and deal } \\
\text { with harassment with } \\
\text { clear reporting and } \\
\text { response procedures. }\end{array}$ & $\begin{array}{l}\text { Percentage of firms } \\
\text { having applied a } \\
\text { harassment control } \\
\text { mechanism. }\end{array}$ \\
\hline
\end{tabular}


Table 6. Cont.

\begin{tabular}{|c|c|c|c|}
\hline \multicolumn{4}{|c|}{ Social Indicators } \\
\hline Topic & $\begin{array}{l}\text { Sub-Topic/Sub- } \\
\text { Category }\end{array}$ & Description & Indicator \\
\hline \multirow{3}{*}{$\begin{array}{l}\text { Social in- } \\
\text { frastructure }\end{array}$} & $\begin{array}{l}\text { Primary social } \\
\text { infrastructure }\end{array}$ & $\begin{array}{l}\text { Social infrastructure } \\
\text { should meet the } \\
\text { standards and } \\
\text { requirements. }\end{array}$ & $\begin{array}{l}\text { Percentage of surveyed } \\
\text { employees of the } \\
\text { workforce and client } \\
\text { prospects. }\end{array}$ \\
\hline & Industrial park security & $\begin{array}{l}\text { Creating effective } \\
\text { security services, such } \\
\text { as suitable lighting } \\
\text { systems in and around } \\
\text { the park, closed-circuit } \\
\text { television systems, a } \\
\text { central security office, } \\
\text { and night } \\
\text { transportation. }\end{array}$ & $\begin{array}{c}\text { Percentage of reported } \\
\text { security and } \\
\text { safety issues. }\end{array}$ \\
\hline & Capacity building & $\begin{array}{c}\text { Training and skills } \\
\text { development programs } \\
\text { per category of } \\
\text { employees, with } \\
\text { emphasis on equal } \\
\text { opportunities. }\end{array}$ & $\begin{array}{c}\text { Percentage of firms } \\
\text { applying relevant } \\
\text { programs. }\end{array}$ \\
\hline \multirow[b]{2}{*}{$\begin{array}{l}\text { Local } \\
\text { community } \\
\text { outreach }\end{array}$} & Community dialogue & $\begin{array}{l}\text { Access to } \\
\text { communication } \\
\text { platforms or other } \\
\text { media to maintain } \\
\text { dialogue with the } \\
\text { community and } \\
\text { relevant civil society } \\
\text { organizations). }\end{array}$ & $\begin{array}{l}\text { Percentage of surveyed } \\
\text { community members. }\end{array}$ \\
\hline & Community outreach & $\begin{array}{l}\text { Discovery of } \\
\text { community outreach } \\
\text { activities by the park } \\
\text { management body and } \\
\text { participating residents. } \\
\text { A relevant annual day } \\
\text { of celebration in the } \\
\text { park could be defined, } \\
\text { public service activities } \\
\text { could be organized in } \\
\text { the community areas } \\
\text { by the park } \\
\text { management, etc. }\end{array}$ & $\begin{array}{l}\text { Number of outreach } \\
\text { activities per year. }\end{array}$ \\
\hline \multicolumn{4}{|c|}{ Economic Indicators } \\
\hline Topic & $\begin{array}{l}\text { Sub-topic/Sub- } \\
\text { category }\end{array}$ & Description & Indicator \\
\hline \multirow{2}{*}{$\begin{array}{l}\text { Job } \\
\text { creation }\end{array}$} & $\begin{array}{l}\text { Generation of local } \\
\text { employment }\end{array}$ & $\begin{array}{l}\text { The BP must create jobs } \\
\text { for the local } \\
\text { community, ensure } \\
\text { revenue links and } \\
\text { growth opportunities. }\end{array}$ & $\begin{array}{l}\text { Percentage of } \\
\text { employees. }\end{array}$ \\
\hline & Type of employment & $\begin{array}{l}\text { The BP should provide } \\
\text { long-term employment } \\
\text { contracts to employees }\end{array}$ & $\begin{array}{l}\text { Ratio of long-term } \\
\text { employment contracts } \\
\text { to total employment } \\
\text { contracts. }\end{array}$ \\
\hline $\begin{array}{l}\text { Local } \\
\text { business } \\
\text { and SMEs } \\
\text { promotion }\end{array}$ & Local value added & $\begin{array}{l}\text { The BP should enable } \\
\text { local businesses to } \\
\text { grow. This can be done } \\
\text { when the BP addresses } \\
\text { local suppliers in a } \\
\text { cost-effective way. }\end{array}$ & Percentage of firms. \\
\hline
\end{tabular}


Table 6. Cont.

\begin{tabular}{|c|c|c|c|}
\hline \multicolumn{4}{|c|}{ Economic Indicators } \\
\hline Topic & $\begin{array}{l}\text { Sub-Topic/Sub- } \\
\text { Category }\end{array}$ & Description & Indicator \\
\hline $\begin{array}{l}\text { Economic } \\
\text { value } \\
\text { creation }\end{array}$ & $\begin{array}{l}\text { Investment-ready park } \\
\text { for firms }\end{array}$ & $\begin{array}{c}\text { A BP must be } \\
\text { "investment-ready" so } \\
\text { as to offer investment } \\
\text { security and better } \\
\text { investment } \\
\text { opportunities to } \\
\text { businesses. Basic } \\
\text { infrastructure services } \\
\text { must be provided by } \\
\text { the industrial park, } \\
\text { including access to } \\
\text { water, energy, roads, } \\
\text { service corridors, etc. }\end{array}$ & $\begin{array}{c}\text { Average percentage } \\
\text { occupancy rate over } \\
\text { last } 5 \text { years. }\end{array}$ \\
\hline
\end{tabular}

Source: Own elaboration based on [38,43,46-48,66,67,72,73,86,88].

The above indicators (schematically presented in Figure 5) reflect the need to modernize the existing spatial and development policies for the organized development of business and industrial activities in Greece. It is, therefore, understood that most of the above do not find full application in the existing "receptors", created in a completely different spatial, development, and environmental policy framework.

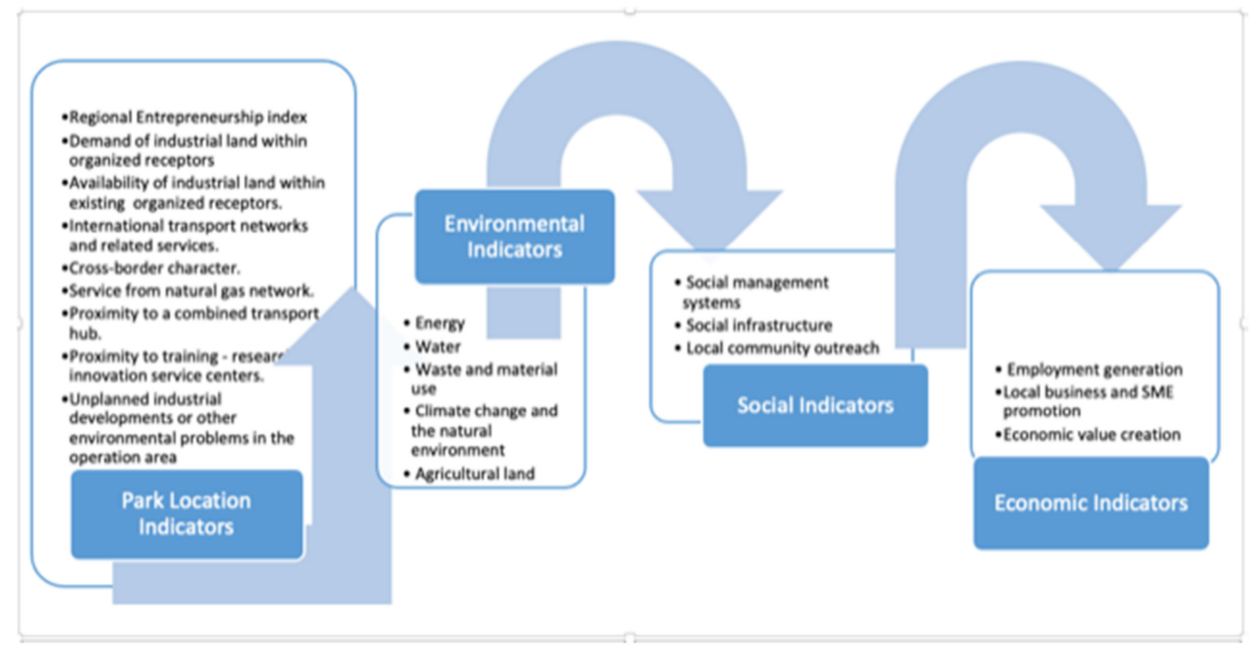

Figure 5. Schematic representation: necessary transformations of development and spatial policies for the modernization of Greek business parks. Source: Own elaboration.

\subsection{Case Study on Local Level: Western Macedonia Business Park}

In order to investigate and evaluate the adaptability of the suggested indicators on a local level, the business park located in Kozani's peri-urban area in Western Macedonia was selected as case study. The case study focused on the analysis of environmental and spatial indicators alone (see Table 7), since measurements and evaluation of the social and economic indicators require on-site research and field recordings that cannot be evaluated at this stage (e.g., job creation and economic value making).

The wider area of the business park (see Figure 4) presents unique development challenges, as it is included among the areas that are part of the Just Transition Development Plan of lignite areas [89]. According to the National Energy and Climate Plan [90], the Greek government has set a goal of withdrawing all lignite plants by 2028, with the majority of units-representing over $80 \%$ of current installed capacity-being withdrawn by 2023 . It is, thus, evident that the local population, which is currently significantly employed in lignite-fired power plants, should look for new employment opportunities to ensure 
sustainable development of the region. It is, therefore, extremely important that the new business park design in the area largely meets modern development conditions, as reflected in the indicators presented earlier. The Western Macedonia BP is being developed at a distance of about $6.5 \mathrm{~km}$ north to the city of Kozani. The municipality of Kozani accounts for 71,388 inhabitants (2011 census) and the region (regional unit) produces $2.3 \%$ of the national Gross Domestic Product (thus ranking ninth in relation to the total of the regions), with $6.8 \%$ coming from farming activities, 38.5\% from the construction industry (including the mining and the energy sector representing $9.8 \%$ and $18.6 \%$, respectively), and $54.7 \%$ from the services sector.

The study area has a total surface of 689.83 acres and is organized to function as a reception area of both business and industrial activities. It has the appropriate urban organization and the required infrastructure projects that can support the business activity. It is expected to operate after the two institutionalized industrial areas of the region of Western Macedonia (Florina Industrial Zone and Kastoria Industrial Zone). This fact gives special weight and importance to the role it can play in the development course of the area and ultimately of the wider region (see Figure 6). The Region of Western Macedonia (PDM) is a remote region bordering Albania and Northern Macedonia (ex Former Yugoslav Republic of Macedonia, FYROM). The position of Kozani's Business Park on the "Egnatia Odos" highway axis gives the area a new development perspective, as two of the nine vertical axes, A27 and A29, cross the regional unit, from south to north, ensuring the integrated road connection of Greece with Albania and Northern Macedonia.
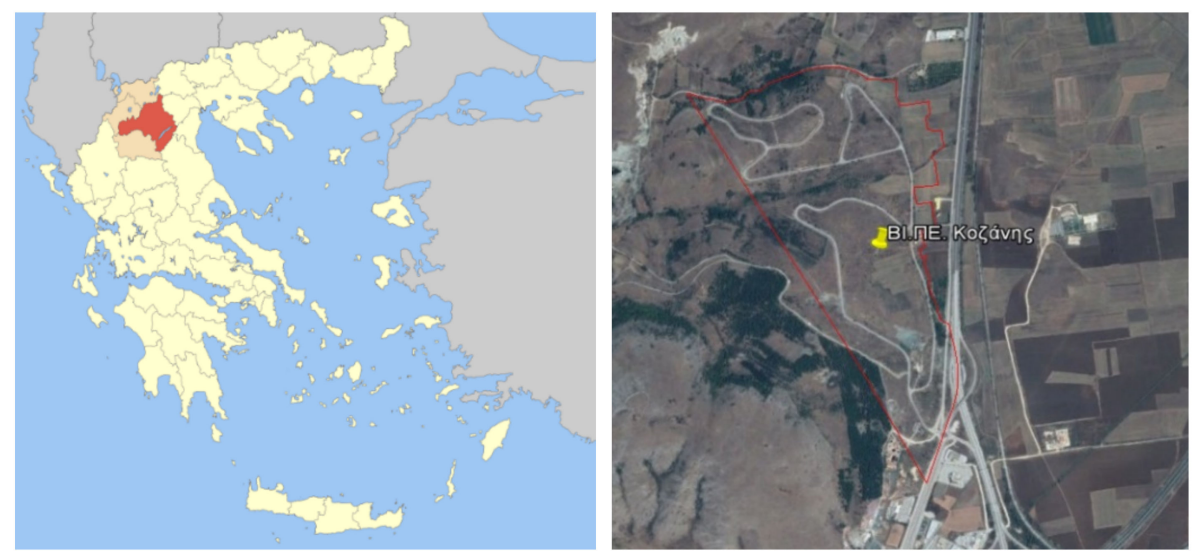

Figure 6. Location of Western Macedonia business park. Source: Environmental impact assessment study for the development of Kozani's business park [91].

Table 7. Investigation for the application of environmental indicators (see Table 6) into the upcoming Western Macedonia business park (WM BP).

\begin{tabular}{|c|c|c|}
\hline \multicolumn{3}{|c|}{ Environmental Indicators in Kozani's Upcoming Business Park } \\
\hline Topic & Sub-Topic & Evaluation Results \\
\hline \multirow{3}{*}{ Energy } & Energy consumption & $\begin{array}{c}\text { Depending on the good practices of } \\
\text { certain firms. Not obligatory. However, } \\
\text { the Hellenic Electricity Distribution } \\
\text { Network Operator }(\Delta \mathrm{E} \Delta \Delta \mathrm{HE}) \text { offers a } \\
\text { service called telemetering that monitors } \\
\text { power consumption for all firms and } \\
\text { industries that use medium } \\
\text { voltage power. }\end{array}$ \\
\hline & Renewable and clean energy & $\begin{array}{l}\text { Not applicable in Greece. All renewable } \\
\text { energy produced is required to be added } \\
\text { to the national energy grid by law and } \\
\text { cannot be used by firms directly. }\end{array}$ \\
\hline & Energy efficiency & $\begin{array}{c}\text { Depending on the good practices of } \\
\text { certain firms. Not obligatory and } \\
\text { not measured. }\end{array}$ \\
\hline
\end{tabular}


Table 7. Cont.

\begin{tabular}{|c|c|c|}
\hline \multicolumn{3}{|c|}{ Environmental Indicators in Kozani's Upcoming Business Park } \\
\hline Topic & Sub-Topic & Evaluation Results \\
\hline \multirow{3}{*}{ Water } & Water consumption & $\begin{array}{l}\text { Water consumption across the park of } \\
\text { Lamia (Lamia Industrial Area) is } \\
\text { automatically measured, using Near } \\
\text { Field Communication (NFC) systems. } \\
\text { Moreover, there is a Supervisory Control } \\
\text { and Data Acquisition (SCADA) system in } \\
\text { place that manages the water extracted } \\
\text { from boreholes depending on demand. } \\
\text { There is also an automatic system that } \\
\text { monitors the quality of wastewater before } \\
\text { it enters the wastewater treatment unit. }\end{array}$ \\
\hline & Water treatment & $\begin{array}{c}100 \% \text { of wastewater treated for all } \\
\text { industrial areas with functional } \\
\text { wastewater treatment units (e.g., Lamia, } \\
\text { Thessaloniki, Irakleio, Patra, Komotini } \\
\text { Industrial Areas). } \\
\text { Another interesting indicator would be } \\
\text { water used/water treated. Water that is } \\
\text { not treated is lost, excluding industries } \\
\text { that use water in their production process } \\
\text { (e.g., breweries). }\end{array}$ \\
\hline & $\begin{array}{l}\text { Water efficiency, reuse } \\
\text { and recycling }\end{array}$ & $\begin{array}{l}0 \% \text { of treated water is provided to be } \\
\text { reused. There is room for improvement, } \\
\text { since the quality of wastewater after } \\
\text { treatment is strictly determined. }\end{array}$ \\
\hline \multirow{3}{*}{$\begin{array}{l}\text { Waste and } \\
\text { material use }\end{array}$} & $\begin{array}{l}\text { Waste/byproduct re-use and } \\
\text { recycling }\end{array}$ & $\begin{array}{l}\text { Solid waste is managed by each } \\
\text { municipality. No information available. }\end{array}$ \\
\hline & Dangerous and toxic materials & $\begin{array}{l}100 \% \text { of firms that have dangerous and } \\
\text { hazardous products / byproducts and that } \\
\text { are located in parks are obliged to } \\
\text { appropriately handle, store, transport, } \\
\text { and dispose of toxic hazardous materials. } \\
\text { Furthermore, there are firms that are } \\
\text { officially licensed to manage dangerous } \\
\text { and toxic materials produced by } \\
\text { other firms. }\end{array}$ \\
\hline & Waste disposal & Same with the above description. \\
\hline \multirow{2}{*}{$\begin{array}{l}\text { Climate change } \\
\text { and the natural } \\
\text { environment }\end{array}$} & $\begin{array}{l}\text { Minimum proportion of open } \\
\text { space in the park for the } \\
\text { maintenance of environmental } \\
\text { balance (cause by the construction } \\
\text { of the park) }\end{array}$ & $\begin{array}{l}\text { Minimum } 25 \% \text { of the BP is open } \\
\text { (prohibited by law). } \\
\text { Minimum } 6 \% \text { of the BP is planned to be } \\
\text { highly vegetized. Moreover, at least } 40 \% \\
\text { of each plot has to remain open space. }\end{array}$ \\
\hline & $\begin{array}{l}\text { Air, GHG emissions, and } \\
\text { pollution prevention }\end{array}$ & $\begin{array}{c}\text { Each firm located in the park has } \\
\text { limitations according to its environmental } \\
\text { licensing decision }\end{array}$ \\
\hline
\end{tabular}

Source: Own elaboration. Based on data from environmental impact assessment study for the development of Kozani's Business Park [91].

The transport system has a direct connection with the Egnatia Highway with five ports and eight airports, two of which are within the same regional unit, as well as with the railway network.

Regarding the data obtained, the following aspects are relevant to the application of the environmental indicators [91]:

- $\quad$ Low energy consumption, i.e., 200,000 MWh per year;

- Water consumption, to not exceed $300 \mathrm{~m}^{3} /$ day;

- The maximum production of liquid waste is estimated equal to $80 \%$ of water consumption;

- Outflows of waste and pollutants depend on the operation of the units to be installed, as the area will be an organized receptor for both industrial and production facilities.

Furthermore, regarding the expected uses and activities that will be installed in the park, the following are provided: landfill, recovery and recycling, including waste 
treatment and energy recovery, special waste management, such as bulky, infectious hospital, toxic, and hazardous materials, production and exploitation of new secondary raw materials, and new methods of energy production in order to ensure the protection of public health and the environment (solid fuels from waste, biogas, soil conditioners/compost, drains, etc.).

\section{Discussion and Policy Recommendations}

Industry in Greece developed in a peculiar environment without neighboring markets and with virtually no hinterland at an equivalent level of development. Its limited growth resulted in fragmented spatial planning arrangements at the local planning level, creating a process of spontaneous, improvised, or even arbitrary residential developments. With regard to the location criteria for industry, it is evident that, with the exception of intensive raw material extraction activities, the majority of industrial activities were located in terms of their vicinity to large urban centers [92,93]. Thus, the Greek industry is dominated by sectors that are oriented toward and dependent on major consumer centers, public and private sector services, the specialization of technical and administrative executives, and organized infrastructure networks (roads, ports, airports, etc.). Athens is recognized as the primary concentration pole and Thessaloniki as the secondary, followed by the major urban centers such as Patras, Heraklion, and the Larissa-Volos dipole.

The majority of manufacturing industries, especially the larger industrial units now seem to have completed their exit cycle from the cities and are looking for establishment options in the peri-urban areas [88,94,95]. All large industries with significant production size choose their locations outside urban settlements, apparently due to incompatibility in terms of possible environmental burdens (nuisance, emissions, etc.) [38].

The modern institution of business parks is at a standstill in Greece, due to a number of inhibitory factors. Their start requires both strategic planning at a national level and a series of management actions within the parks. The former is related to the development of cities and to the economic functions of large urban centers supporting the industrial base, as well as to the wider value chains, in the context of the globalized economy. A network of dynamic cities is essential for business park development and vice versa; business parks fuel the dynamics of urban centers and support their sustained inclusion in competitive networks. It is, therefore, necessary to prioritize urban agglomerations in which business parks could be developed, possibly also with a thematic approach (assessment of cities, with the requirement for more specific criteria for the creation of receptors, such as conventional and intangible infrastructure networks, motorways, and land prices).

Existing spatial organization seems to pose obstacles to attracting investments and is a brake for the competitiveness of Greek industry and its ability to meet future challenges. Current international evolutions and the need for local economies to adapt to them in order to increase their resilience call for a clearer and more effective link between spatial and development planning. In this context, the authors believe that, in order to enhance the attractiveness of business parks, several guiding principles (see Table 8) are needed, consistent with the basic principles required for the creation of modern BPs.

Table 8. Guiding principles to adapt BPs to current trends and enhance their attractiveness.

\begin{tabular}{ccc}
\hline $\begin{array}{c}\text { Guiding } \\
\text { Principles/Recommendations }\end{array}$ & General Trends & Specific Results \\
\hline $\begin{array}{l}\text { Improving planning terms and } \\
\text { conditions for the development } \\
\text { of activities within “Organized } \\
\text { receptors of manufacturing and } \\
\text { business activities" (OYMEDs). }\end{array}$ & $\begin{array}{c}\text { Supporting the circular economy } \\
\text { and green growth. }\end{array}$ & $\begin{array}{c}\text { Development of } \\
\text { industrial symbiosis } \\
\text { and eco- } \\
\text { Promoting planning and } \\
\text { environmental remediation of } \\
\text { informal industrial } \\
\text { concentrations (IICs). }\end{array}$ \\
\hline
\end{tabular}


Table 8. Cont.

\begin{tabular}{|c|c|c|}
\hline $\begin{array}{c}\text { Guiding } \\
\text { Principles/Recommendations }\end{array}$ & General Trends & Specific Results \\
\hline $\begin{array}{c}\text { Initiating a transparent and } \\
\text { evidence-based strategic } \\
\text { planning that will promote } \\
\text { synergistic effects between } \\
\text { policies (industrial and spatial } \\
\text { planning) and public and private } \\
\text { institutions/actors. } \\
\text { Taking into account performance } \\
\text { indicators based also on the } \\
\text { international EIPs framework: } \\
\text { location indicators, } \\
\text { environmental indicators, social } \\
\text { indicators, economic indicators. }\end{array}$ & $\begin{array}{c}\text { Cooperation of industry, } \\
\text { government, universities, and } \\
\text { nonprofit research institutes in } \\
\text { order to develop } \\
\text { technology-intensive industries. } \\
\text { Consensus among industry, } \\
\text { government, and academia on } \\
\text { the initial development of the } \\
\text { high-tech industry with growth } \\
\text { potential and broad } \\
\text { interdependence between } \\
\text { industries. } \\
\text { Designing and implementing an } \\
\text { evidence-based policy for } \\
\text { industrial activities to also } \\
\text { provide data related to EIPs } \\
\text { performances. }\end{array}$ & $\begin{array}{l}\text { Promotion of sci-tech } \\
\text { parks, supporting new } \\
\text { technologies and } \\
\text { Industry } 4.0 .\end{array}$ \\
\hline
\end{tabular}

Source: Own elaboration by authors.

In this respect, support must be provided to innovation and entrepreneurship, to business clusters both within and outside cities, and to linking industry to education, agriculture, and other seemingly incompatible uses and functions into a quality whole, while also taking advantage of the inputs from universities and research centers.

The authors believe that immediate initiatives are required, which will contribute to increasing the attractiveness of the institution of business parks. Additionally, given the particularities of the Greek territory, all informal industrial concentrations (IICs) should be organized as a matter of priority, in the immediate future. Business parks, viewed as a mechanism linking spatial to development planning, appear to offer a solution for restoring and strengthening the productive potential of the Greek economy, for developing industry, and for attracting investments. Taking also into account the fact that an unprecedented planning project is currently underway for the completion of spatial planning in the Greek territory, a series of priority recommendations can be proposed. For instance, it is critical to specify the criteria for the location process of new business parks, to ensure suitability (transport networks, tangible and intangible infrastructure, availability of resources, etc.) and identify current and future needs of the areas suitable for the development of "organized receptors".

Another recommendation can be the promotion of the planning and environmental remediation of informal industrial concentrations (IICs). In particular, financial and fiscal incentives and better planning and development standards are needed for the remediation of business parks. The definition of these particular zones will require synergies with the new town plans: (a) the "local urban plans" (see Table 1, p. 7) that are previewed to broadly cover a large part of the Greek territory ( $80 \%$ instead of the current $20 \%$ ), on a 6-year horizon and (b) the "special spatial plans" (see Table 1, p. 7), since productive activities have amplified needs in these areas and require a specialized planning approach, involving also the private sector.

Critical recommendations are both the assessment of social and environmental factors in relation to national requirements and international commitments (on climate neutrality, new energy planning, biodiversity conservation, green infrastructure, etc.) and the thematic enrichment of the available types of business parks, with emphasis on those supporting new technologies and Industry 4.0, the circular economy, and green growth.

It is also essential to model the impacts of a business park on the urban system in terms of urban development, land use, infrastructure, and transport networks (both conventional and ICT-based), as well as to improve the planning terms and conditions for the development of activities within organized receptors. In this way, the latter may be more competitive and efficiently attract businesses. Moreover, to the extent that business 
parks can support business clusters, it is easily understood that existing and future spatial and development policies should include initiatives to jointly promote business clusters and business parks.

Promotion of a technology-intensive industry is often the guiding principle (cf. Table 8) for the development of countries with a small-scale domestic market. To this end, it is often necessary to provide subsidies and tax incentives to research institutes. Similarly, in addition to encouraging universities to diffuse knowledge for industrial development, the cooperation of industry, government, universities, and non-profit research institutes is critical for an innovation system well embedded in the Greek economy. Creating an innovation system requires consensus among industry, government, and academia on the initial development of the high-tech industry with growth potential and broad interdependence across industries [96].

Innovation is also a factor that influences the formation and development of industrial symbiosis complexes, through improvements in material utilization and reuse technologies, and the adjustment of industrial production structures. In the circular economy context, innovation could be an effective strategy to improve the eco-efficiency. The concept of ecoindustrial parks and innovation (EIP) forms, along with the concept of industrial symbioses (ISs), the body of industrial ecology (IE) [96]. According to Frosch and Gallopoulos [97], through imitation of the cyclic nature flows, the industrial symbiosis is responsible for reducing the consumption of natural resources, as well as the generation of waste. Moreover, through the EIPs, the IE develops trade networks in order to promote the conservation of resources [98].

Additionally, industrial parks are gradually becoming key loci where universities and scientific research institutions develop advanced technology and test the efficiency of their scientific research achievements. There is actually an enhanced mutual influence and cooperation between higher education institutions (HEIs) and businesses. Successful cases of sci-tech parks, such as Stanford University, Silicon Valley, the MIT industrial cluster, and the highway 128 in Boston, are generally located close to universities, colleges, scientific research institutions, and other intellectual resources. In this way, a strong intellectual support is provided for the development of sci-tech parks and cities. Additionally, the strategic location of these parks can enable a close integration of "industries, universities, and research", gradually forming a growth chain of innovation and industry clusters.

Innovation is additionally the primary driving force behind the development and strategic support of the construction of a modern economic system. Regarding the impact of proximity to universities on enterprise innovation, scholars generally believe that spatial proximity between universities and companies promotes synergies between these organizations. Geographic proximity between academic institutions and enterprises is considered extremely important for innovation [99], as it is conducive to the establishment of connections between them and to transfers of knowledge, especially that of tacit knowledge [99]. A study on the driving factors behind school-enterprise cooperative innovation [100] proved that enterprises within $150 \mathrm{~km}$ of a university have more product innovation possibilities than those located far from a university.

Given the above, the authors believe that sci-tech-parks gathering a large number of businesses developing science and technology innovation industries can be the driving force for new urbanization and for the creation of urban innovative space in Greece. Lastly, it is considered necessary to learn from international experience about the joint operation of business clusters with business parks, so as to launch successful organizational forms of clusters in the Greek territory.

On a more general mote, the authors believe that better coordination between industrial policy and spatial planning policy is needed. This can be achieved by setting up an inter-ministerial body which may function as a "high-level commission for territorial development", modeled on the French DATAR (Délégation Interministérielle à l'Aménagement du Territoire et à l'Attractivité Régionale) at the highest level of government, reporting to the Prime Minister [101-103]. Such a mechanism may add to integrated territorial develop- 
ment policies, often hampered by sectorial interests. Such a scheme must be endowed with strong coordination responsibilities, the capacity to conduct participatory planning with the efficient and inclusive involvement of all relevant stakeholders from the very beginning of the process, and mainly the capacity to produce relevant evidence. The recent enactment of the law 4759/2020 that aspires to modernize the urban and spatial planning legislation should be complemented with such mechanisms that will certainly facilitate sustainable and integrated territorial development strategies in the country.

\section{Conclusions}

This research paper analyzed the organization and spatial distribution of industrial activities in Greece and the ongoing renewal of the industrial location in the country. It attempted a description of the situation of "business parks" in Greece, highlighting the key constraints hampering their development and the fact that the existing spatial organization is inefficient in terms of attracting investment and add competitiveness to Greek industry. To this end, the paper explored new concepts and trends that may be adopted by the Greek business parks, for them to become attractive and able to meet future challenges. The concepts explored were mainly industrial symbiosis, sci-tech-parks which may be a driving force for the creation of an innovative urban space, the innovation concept, and the eco-industrial parks (EIPs). Particularly, the latter inspired the authors to construct a set of indicators adapted to the specific needs of the Greek industrial parks, appropriate for assessing and monitoring the performance of business parks and enabling their transformation in EIPs. Particular emphasis was placed on the concept of location, since it allows detection of resources and capabilities. These concepts were the result of the interaction of all the localized-self-reproduced and self-reinforced-components in the spatial context including the strategies of located firms, capable of untapping territorial potential. Lastly, an effort to apply this system of indicators on a national and local level led to the identification of existing gaps.

Findings support the need to proceed to an immediate comprehensive review of the regulatory and operational framework regarding business parks so as to (a) increase synergies of industrial activities with territorial policies, (b) establish collaborative mechanisms acting as catalysts for creativity and innovation, (c) introduce a system of indicators to monitor business park development on the basis of the international framework for eco-industrial parks (EIPs), (d) pursue an evidence-based industrial policy on national and local levels and (e) adopt a place-based approach for specific territories like for example the insular ones. A critical conclusion is also the establishment of a high-level inter-ministerial body to ensure strong coordination between spatial and industrial policy.

It is expected that the paper's considerations and facts may enable policymakers to identify appropriate actions for the development of business park resources and capabilities, which could enable their efficient networking and allow a better performance of Greek business parks in the context of the global competition.

Author Contributions: Conceptualization, A.G., S.S.K. and I.L.; methodology, A.G., S.S.K. and I.L.; validation, A.G., S.S.K. and I.L.; formal analysis, A.G., S.S.K. and I.L.; investigation, A.G., S.S.K. and I.L.; resources, A.G. and I.L.; data curation, A.G. and I.L.; writing-original draft preparation, A.G., S.S.K. and I.L.; writing-review and editing, A.G. and S.S.K.; visualization, A.G., S.S.K. and I.L.; supervision, A.G. and S.S.K. All authors have read and agreed to the published version of the manuscript.

Funding: This research received no external funding.

Institutional Review Board Statement: Not applicable.

Informed Consent Statement: Not applicable.

Data Availability Statement: Data in this research are either publicly available or obtained from Greek authorities (Ministries etc.) and are available with the permission of these authorities, as these are cited by authors. 
Acknowledgments: The authors would like to thank the three anonymous reviewers for their precious comments.

Conflicts of Interest: The authors declare no conflict of interest.

\section{References}

1. Healey, P. Collaborative Planning Shaping Places in Fragmented Societies, 2nd ed.; Palgrave MacMillan: London, UK, 2006.

2. Newman, P.; Thornley, A. Planning World Cities: Globalization and Urban. Politics, 2nd ed.; Palgrave Macmillan: London, UK, 2011.

3. Gourgiotis, L. Spatial Planning and Industrial Activities in the European Union with Special Focus in Greece: Policies and Perspectives on Industrial Development. Ph.D. Thesis, Aristotle University of Thessaloniki, Thessaloniki, Greece, 2012. Available online: https: / / www.didaktorika.gr/eadd/handle/10442/27436 (accessed on 21 December 2020).

4. European Commission. ESDP-European Spatial Development Perspective. Available online: https://ec.europa.eu/regional_ policy/sources/docoffic/official/reports/pdf/sum_en.pdf (accessed on 19 November 2020).

5. Scott, A.J. Regions and the World Economy: The Coming Shape of Global Production, Competition, and Political Order; Oxford University Press: Oxford, UK, 2000. [CrossRef]

6. Ministry of Environment, Spatial Planning and Public Works. Study for the Special Spatial Plan for Industry; Ministry of Environment, Spatial Planning and Public Works: Athens, Greece, 2007.

7. Krumme, G. Toward a Geography of Enterprise. Econ. Geogr. 1969, 45, 30. [CrossRef]

8. Hamilton, F.E.I. Spatial Perspectives on Industrial Organization and Decisionmaking; John Wiley: Chichester, UK, 1974.

9. Chapman, K. Corporate Systems in the United Kingdom Petrochemical Industry. Ann. Assoc. Am. Geogr. 1974, 64, 126-137. [CrossRef]

10. Taylor, M.J. Organizational Growth, Spatial Interaction and Location Decision-Making. Reg. Stud. 1975, 9, 313-323. [CrossRef]

11. Kourliouros, E. Paths in the Theories of Space, Economic Geographies of Production and Development; Ellinika Grammata: Athens, Greece, 2001.

12. Perroux, F. Note Sur La Notion de Pôle de Croissance. Econ. Appl. 1955, 8, 307-320.

13. Boudeville, J.-R. Problems of Regional Economic Planning. Rech. Econ. Louvain Louvain Econ. Rev. 1969, 35, 161. [CrossRef]

14. Konsolas, N.I. Modern Regional Economic Policy; Papazissis: Athens, Greece, 1997. (In Greek)

15. Richardson, H.W. Regional Economics; Papazissis: Athens, Greece, 1972. (In Greek)

16. Kyvelou, S. From Spatial Planning to Spatial Management: Strategic Spatial Planning and Territorial Cohesion in Europe; Kritiki Publishing: Athens, Greece, 2010.

17. Kyvelou, S.; Sinou, M.; Baer, I.; Papadopoulos, T. Developing a South-European Eco-Quarter Design and Assessment Tool Based on the Concept of Territorial Capital. In Sustainable Development-Authoritative and Leading Edge Content for Environmental Management; Curkovic, S., Ed.; InTechOpen: London, UK, 2012; pp. 561-588. [CrossRef]

18. Di Milano, P.; Camagni, R.; Caragliu, A.; Perucca, G. Il Capitale Territoriale: Scenari Quali-Quantitativi di Superamento della Crisi Economica e Finanziaria per le Province Italiane Territorial Capital Relational and Human Capital. Available online: http:/ / www.grupposervizioambiente.it/aisre/pendrive2011/pendrive/Paper/Camagni_Caragliu_Perucca.pdf (accessed on 21 February 2021).

19. Kunzmann, K.R. The ESDP, the New Territorial Agenda and the Periphery in Europe. In The ESDP and Spatial Development of Peripheral Regions; Farrugia, N., Ed.; Malta University Publishers Limited: Valetta, Malta, 2007.

20. ESPON 2014-2020. Applied Research Project, Small and Medium-Sized Enterprises in European Regions and Cities. Available online: https: / / www.espon.eu/sites/default/files/attachments/SmallandMedium-sizedEnterprisesinEuropeanRegionsandCities. pdf (accessed on 21 February 2021).

21. Andrikopoulou, E.; Giannakou, A.; Kafkalas, G.; Pitsiava-Latinopoulou, M. City and Urban. Planning Practices for Sustainable Development, 2nd ed.; Kritiki Publishing: Athens, Greece, 2014.

22. European Commission. Directorate-General for Internal Market, Industry, Entrepreneurship and SMEs, Annual Report on European SMEs 2014/2015 SMEs Start Hiring Again. Available online: https:/ / www.ggb.gr/sites/default/files/basic-pagefiles/2015_annual-report_en.pdf (accessed on 20 December 2020).

23. Marshall, A. Principles of Economics, 8th ed.; Macmillan and Co.: London, UK, 1920.

24. Porter, M.E. Locations, Clusters and Company Strategy. In The Oxford Handbook of Economic Geography; Clark, G., Feldman, L., Gertler, M., Eds.; Oxford University Press: Oxford, UK, 2000; pp. 253-274.

25. Jacobs, J. The Economy of Cities; Vintage: New York, NY, USA, 1969.

26. Doloreux, D.; Shearmur, R.; Figueiredo, D. Québec' Coastal Maritime Cluster: Its Impact on Regional Economic Development, 2001-2011. Mar. Policy 2016, 71, 201-209. [CrossRef]

27. Porter, M. Local Clusters in a Global Economy. In Creative Industries; Hartley, J., Ed.; Blackwell Publishing: Hoboken, NJ, USA, 2005; pp. 259-267.

28. Krugman, P. Geography and Trade; Leuven University Press and The MIT Press: Cambridge, MA, USA, 1991.

29. Elola, A.; Valdaliso, J.M.; López, S.M.; Aranguren, M.J. Cluster Life Cycles, Path Dependency and Regional Economic Development: Insights from a Meta-Study on Basque Clusters. Eur. Plan. Stud. 2012, 20, 257-279. [CrossRef]

30. Doloreux, D.; Shearmur, R. Moving Maritime Clusters to the next Level: Canada's Ocean Supercluster Initiative. Mar. Policy 2018, 98, 33-36. [CrossRef] 
31. Klepper, S. The Evolution of Geographic Structure in New Industries. In Applied Evolutionary Economics and Economic Geography; Frenken, K., Ed.; Edward Elgar Publishing: Cheltenham, UK, 2007; pp. 1-2. [CrossRef]

32. Shahab, S.; Viallon, F.-X. Swiss Land Improvement Syndicates: 'Impure' Coasian Solutions? Plan. Theory 2021, 20 , 44-62. [CrossRef]

33. Buitelaar, E. A Transaction-Cost Analysis of the Land Development Process. Urban Stud. 2004, 41, 2539-2553. [CrossRef]

34. Alexander, E.R. A Transaction Cost Theory of Planning. J. Am. Plan. Assoc. 1992, 58, 190-200. [CrossRef]

35. Healey, P. An Institutional Model of the Development Process. J. Prop. Res. 1992, 9, 33-44. [CrossRef]

36. Economou, D. Spatial Planning System: Greek Reality and International Experience. Rev. Soc. Res. 2000, 1, 3-57. [CrossRef]

37. Dimitropoulou, C. On the Location of Industrial Activities. Available online: https://nomosphysis.org.gr/12329/perixorothetisis-biomixanikon-drastiriotiton-noembrios-2011/ (accessed on 20 December 2020).

38. General Secretariat for Industry. Business Plan for the Development of Business Parks in the Greek Territory, Volume: Summary-Conclusions. Available online: http://www.ggb.gr/sites/default/files/basic-page-files/KEIMENO_\$ $\backslash$ protect

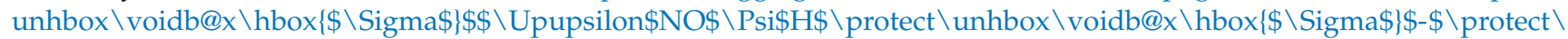
unhbox \voidb@x \hbox $\{\backslash$ Sigma\$\}\$Upupsilon\$M\$Pi\$EPA\$protect \unhbox \voidb@x \hbox $\{\$$ Sigma\$\}MATA.pdf\# overlay-context=el/node/1274 (accessed on 20 January 2021).

39. Greek Government. Gazette 151/AAP, Special Spatial Planning Framework for Industry (SSPFI). Available online: http: //ypen.gov.gr/wp-content/uploads/2020/11/FEK151_AAP_2009_Viomixania.pdf (accessed on 15 November 2020).

40. Tsilimigkas, G.; Kizos, T.; Gourgiotis, A. Unregulated Urban Sprawl and Spatial Distribution of Fire Events: Evidence from Greece. Environ. Hazards 2018, 17, 436-455. [CrossRef]

41. Tsilimigkas, G.; Pafi, M.; Gourgiotis, A. Coastal Landscape and the Greek Spatial Planning: Evidence from Windpower in the South Aegean Islands. J. Coast. Conserv. 2018, 22, 1129-1142. [CrossRef]

42. Greek Government. Gazette A/245, Law 4759/2020 Modernization of Spatial and Urban Planning Legislation and Other Provisions. Available online: http://www.et.gr/idocs-nph/search/pdfViewerForm.html?args=5C7QrtC22wHUdWr4 xouZundtvSoClrL8q6KUEZFb2m55MXD0LzQTLWPU9yLzB8V68knBzLCmTXKaO6fpVZ6Lx9hLs1JUqeiQLJ7Vg25AkRIa4 FAYZkvoml0j34N1AdWSHQqfbwznl5Y (accessed on 20 January 2021).

43. Baldassarre, B.; Schepers, M.; Bocken, N.; Cuppen, E.; Korevaar, G.; Calabretta, G. Industrial Symbiosis: Towards a Design Process for Eco-Industrial Clusters by Integrating Circular Economy and Industrial Ecology Perspectives. J. Clean. Prod. 2019, 216, 446-460. [CrossRef]

44. Chertow, M.; Ehrenfeld, J. Organizing Self-Organizing Systems. J. Ind. Ecol. 2012, 16, 13-27. [CrossRef]

45. Ellen MacArthur Foundation. Towards a Circular Economy: Business Rationale for an Accelerated Transition. Available online: https:/ / www.ellenmacarthurfoundation.org/assets/downloads/TCE_Ellen-MacArthur-Foundation-9-Dec-2015.pdf (accessed on 2 June 2020).

46. Genc, O.; van Capelleveen, G.; Erdis, E.; Yildiz, O.; Yazan, D.M. A Socio-Ecological Approach to Improve Industrial Zones towards Eco-Industrial Parks. J. Environ. Manag. 2019, 250, 109507. [CrossRef] [PubMed]

47. Gibbs, D.; Deutz, P. Reflections on Implementing Industrial Ecology through Eco-Industrial Park Development. J. Clean. Prod. 2007, 15, 1683-1695. [CrossRef]

48. Lambert, A.J.D.; Boons, F.A. Eco-Industrial Parks: Stimulating Sustainable Development in Mixed Industrial Parks. Technovation 2002, 22, 471-484. [CrossRef]

49. European Commission. Communication for the Commission: The European Green Deal. Available online: https://eur-lex. europa.eu/legal-content/EN/TXT/?qid=1588580774040\&uri=CELEX:52019DC0640 (accessed on 23 November 2020).

50. Schwab, K. The Fourth Industrial Revolution; World Economic Forum: Geneva, Switzerland, 2017.

51. United Nations Industrial Development Organization (UNIDO). Industrial Development Report, Industrializing in the Digital Age. Available online: https://in.one.un.org/industrializing-for-economic-recovery-in-the-digital-age/ (accessed on 3 June 2020).

52. World Economic Forum (WEF). The Fourth Industrial Revolution: What It Means, How to Respond. Available online: https: //www.weforum.org/agenda/2016/01/the-fourth-industrial-revolution-what-it-means-and-how-to-respond/ (accessed on 5 June 2020).

53. High Level Group on Energy Intensive Industries, Masterplan for a Competitive Transformation of EU Energy-Intensive Industries Enabling a Climate-neutral, Circular Economy by 2050—Report. Available online: https://ec.europa.eu/docsroom/ documents/38403/attachments/1/translations/en/renditions/native (accessed on 3 June 2020).

54. European Commission. Communication for the Commission: A New Industrial Strategy for Europe. Available online: https: / / eur-lex.europa.eu/legal-content/EN/TXT/HTML/?uri=CELEX:52020DC0102\&from=EL (accessed on 3 June 2020).

55. Lainas, I. Changes in Town Planning for the Organised Development Business Activities: Institutional Development and Necessary Reforms. Environ. Law Spec. Issue Urban Plan. Real Estate Dev. 2019, 3, 415-426.

56. United Nations Industrial Development Organization (UNIDO). International Guidelines for Industrial Parks. Available online: https:/ / www.unido.org/sites/default/files / files/2020-05/International_Guidelines_for_Industrial_Parks_EN_0.pdf (accessed on 4 June 2020).

57. United Nations (UN). Industrial Development for the 21st Century. Available online: https://sustainabledevelopment.un.org/ content/documents/full_report.pdf (accessed on 3 June 2020). 
58. United Nations Industrial Development Organization (UNIDO). Demand for Manufacturing: Driving Inclusive and Sustainable Industrial Development. Available online: https:/ /www.unido.org/sites/default/files/files/2017-11/IDR2018_FULLREPORT. pdf (accessed on 3 June 2020).

59. Castells, M. The Rise of the Network Society; Blackwell: Oxford, UK, 1996.

60. Golley, J. Industrial Location and Regional Development. In China: New Engine of World Growth; Garnaut, R., Song, L., Eds.; ANU Press: Canberra, Australia, 2012; pp. 404-433. [CrossRef]

61. Baldwin, R.E.; Okubo, T. Heterogeneous Firms, Agglomeration and Economic Geography: Spatial Selection and Sorting. J. Econ. Geogr. 2006, 6, 323-346. [CrossRef]

62. Batty, M. Cities and Complexity. Understanding Cities with Cellular Automata, Agent-Based Models, and Fractals; MIT Press: Harvard, MA, USA, 2005.

63. Boschma, R.A.; Wenting, R. The Spatial Evolution of the British Automobile Industry: Does Location Matter? Ind. Corp. Chang. 2007, 16, 213-238. [CrossRef]

64. Boschma, R.A. Competitiveness of Regions from an Evolutionary Perspective. Reg. Stud. 2004, 38, 1001-1014. [CrossRef]

65. International Labour Organization (ILO). Transforming Economies: Making Industrial Policy Work for Growth, Jobs and Development. Available online: https://www.ilo.org/wcmsp5/groups/public/---dgreports/---dcomm/---publ/documents/ publication/wcms_242878.pdf (accessed on 3 June 2020).

66. Conticelli, E.; Tondelli, S. Eco-Industrial Parks and Sustainable Spatial Planning: A Possible Contradiction? Adm. Sci. 2014, 4, 331-349. [CrossRef]

67. OECD, Industrial Policy and Territorial Development. Lessons from Korea. Available online: https://www.oecd.org/ development/development-philanthropy /50560264.pdf (accessed on 5 June 2020).

68. Aiginger, K. Industrial Policy for a Sustainable Growth Path. Available online: https://www.oecd.org/economy/IndustrialPolicy-for-a-sustainable-growth-path.pdf (accessed on 20 June 2020).

69. Research Triangle Park (RTP). The Research Triangle Park Master Plan. Available online: https://files.rtp.org/wp-content/ uploads /2014/08/CONCISE-MASTER-PLAN.pdf (accessed on 20 June 2020).

70. Battaglia, A.; Tremblay, D.-G. 22@ and the Innovation District in Barcelona and Montreal: A Process of Clustering Development between Urban Regeneration and Economic Competitiveness. Urban Stud. Res. 2011, 2011, 1-17. [CrossRef]

71. Baas, L. Industrial Symbiosis in the Rotterdam Harbour and Industry Complex: Reflections on the Interconnection of the Techno-Sphere with the Social System. In Business Strategy and the Environment; Wiley Online Library: Hoboken, NJ, USA, 2008; Volume 17, pp. 330-340. [CrossRef]

72. Farel, R.; Charrière, B.; Thevenet, C.; Yune, J.H. Sustainable Manufacturing through Creation and Governance of Eco-Industrial Parks. J. Manuf. Sci. Eng. Trans. ASME 2016, 138. [CrossRef]

73. Philp, J.; Winickoff, D. Innovation Ecosystems in the Bioeconomy. Available online: https://www.oecd-ilibrary.org/science-andtechnology/innovation-ecosystems-in-the-bioeconomy_e2e3d8a1-en (accessed on 6 June 2020).

74. Feferman, G. Brazil: Good Governance in the Tropics-The Rise of the Porto Digital Cluster of Innovation. In Global Clusters of Innovation: Entrepreneurial Engines of Economic Growth around the World; Engel, J.S., Ed.; Edward Elgar Publishing: Cheltenham, UK, 2014; pp. 296-338.

75. Mangana-Kakaounaki, S. Industrial Location in Greece and the Role of Organised Receptors for Businesses. In Presentation in the Conference "France-Greece: Exchange of Experiences in Spatial Planning"; University of Thessaly and the French Institute of Athens (IFA): Athens, Greece, 2020; Unpublished Work.

76. Foundation for Economic and Industrial Research (IOVE). Economic, Social and Environmental Footprint of the Operation of the Organised Receptors of Activities: The Importance of ETVA VIPE. Available online: http://iobe.gr/docs/research/RES_05_F_03 122019_PRE_GR.pdf (accessed on 3 June 2020).

77. Hellenic Federation of Enterprises (SEV). Special Report: Business Parks as Key to the Industrial Restructuring of the Economy and to Attracting Investments. Available online: https://www.sev.org.gr/Uploads/Documents/50520/special_report_27_9_2017.pdf (accessed on 17 June 2020).

78. Greek Government. Regional Spatial Planning Framework of Western Greece. Available online: https://ypen.gov.gr/wpcontent/uploads/2021/01/FEK845D_2020.pdf (accessed on 15 January 2021).

79. Greek Government. Regional Spatial Planning Framework of Central Macedonia. Available online: http://ypen.gov.gr/wpcontent/uploads/2020/11/FEK485\%CE\%94_2020_PKM.pdf (accessed on 15 January 2021).

80. Greek Government. Regional Spatial Planning Framework of North Aegean. Available online: http://ypen.gov.gr/wp-content/ uploads/2020/11/20200728_B_Aigaioy_FEK.pdf (accessed on 15 January 2021).

81. Greek Government. Regional Spatial Planning Framework of Eastern Macedonia and Thrace. Available online: http://ypen.gov. gr/wp-content/uploads/2020/11/20200728_An_Makedonia_Thraki_FEK.pdf (accessed on 15 January 2021).

82. Greek Government. Regional Spatial Planning Framework of Central Greece. Available online: http://ypen.gov.gr/wp-content/ uploads/2020/11/20200728_Sterea_Ellada_FEK.pdf (accessed on 15 January 2021).

83. Greek Government. Regional Spatial Planning Framework of Thessaly. Greek Government. Regional Spatial Planning Framework of Epirus. Available online: http:/ /ypen.gov.gr/wp-content/uploads/2020/11/20200728_Hpeiros_FEK.pdf (accessed on 15 January 2021). 
84. Greek Government. Regional Spatial Planning Framework of Crete. Available online: http://ypen.gov.gr/wp-content/uploads/ 2020/11/20200728_Krhth_FEK.pdf (accessed on 15 January 2021).

85. Greek Government. Regional Spatial Planning Framework of Ionian Islands. Available online: http://ypen.gov.gr/wp-content/ uploads/2020/11/20200728_Ionia_FEK.pdf (accessed on 15 January 2021).

86. World Bank Group. An international Framework for Eco-Industrial Parks. Available online: https://openknowledge.worldbank. org/bitstream/handle/10986/29110/122179-WP-PUBLIC-AnInternationalFrameworkforEcoIndustrialParks.pdf (accessed on 15 June 2020).

87. European Commission. European Green Deal. Available online: https://ec.europa.eu/commission/presscorner/detail/en/fs_ 19_6714 (accessed on 15 June 2020).

88. UN Habitat. The Economic Role of Cities. Available online: http://urban-intergroup.eu/wp-content/files_mf/economicroleofcities_ unhabitat11.pdf (accessed on 4 October 2020).

89. Ministry of Environment and Energy. Just Transition Development Plan of Lignite Areas. Available online: https://www.sdam. gr/sites/default/files/consultation/Master_Plan_Public_Consultation_ENG.pdf (accessed on 21 January 2021).

90. Greek Government. Gazette 4893/B, National Energy and Climate Plan. Available online: https:/ / rb.gy / x4bxbk (accessed on 21 January 2021).

91. Environmental Impact Assessment Study for the Development of Kozani's Business Park, Athens, Greece, 2020; Unpublished Work.

92. United Nations Industrial Development Organization (UNIDO). Cities at a Crossroads: Unlocking the Potential of Industries in Sustainable Urban Development. Available online: https:/ / eu.eventscloud.com/file_uploads/df8ae89f48313dade60b3dc88026 bd9b_OBOR_InclusiveandSustainableCityExhibitionandDialogue_IssuePaper_FINAL.pdf (accessed on 3 June 2020).

93. Mathis, F. Industrial Development through Urbanization: A New Theory on Poverty and Prosperity; University of New Orleans Press: New Orleans, LA, USA, 2015. [CrossRef]

94. European Union. Cities of Tomorrow. Challenges, Visions, Ways Forward. Available online: https://ec.europa.eu/regional_ policy/sources/docgener/studies/pdf/citiesoftomorrow/citiesoftomorrow_final.pdf (accessed on 2 June 2020).

95. Hall, P.; Pain, K. The Polycentric Metropolis: Learning from Mega-City Regions in Europe; Routledge: London, UK, 2009.

96. Campos-Silva, W.L.; Neto, J.A.; Sousa, M.F.; Yaryd, R.T. Innovation in Eco-Industrial Parks: A Comparative Review of Case Studies. Available online: https:/ / www.semanticscholar.org/paper/Innovation-in-eco-industrial-parks-\%3A-a-comparativeCampos-Silva-Neto/eeb58202ead644415fdeff171f4c6f57869a1a43 (accessed on 22 February 2021).

97. Frosch, R.A.; Gallopoulos, N.E. Strategies for Manufacturing. Sci. Am. 1989, 261, 144-152. [CrossRef]

98. Aviso, K.B. Design of robust water exchange networks for eco-industrial symbiosis. Process. Saf. Environ. Prot. 2014, 92, 160-170. [CrossRef]

99. Hervas-Oliver, J.-L.; Albors-Garrigos, J. The Role of the Firm's Internal and Relational Capabilities in Clusters: When Distance and Embeddedness Are Not Enough to Explain Innovation. J. Econ. Geogr. 2008, 9, 263-283. [CrossRef]

100. Maietta, O.W. Determinants of University-Firm R\&D Collaboration and Its Impact on Innovation: A Perspective from a Low-Tech Industry. Res. Policy 2015, 44, 1341-1359. [CrossRef]

101. Kyvelou, S. Governance, space and sustainable development: Networks of services and urban/city networks. In Review of Administrative Science; Sakkoulas Publications: Athens, Greece, 1998; Volume 4, pp. 183-225. (In Greek)

102. Kyvelou, S. The Administration in Space: Relocation of Services and Organisations in the Periphery, Urban Deconcentration and National Spatial Planning, Problems of Administrative Reform. In Series ADMINISTRATION and STATE; Sakkoulas Publications: Athens-Komotini, Greece, 1995; pp. 253-273. (In Greek)

103. Gourgiotis, A.; Tsilimingas, G. A New Approach to Spatial Planning in Greece. Aeichoros, Texts T. Plan. Spat. Plan. Dev. 2016, $26,103-122$. 